\title{
CONFLITO ENTRE O DEVER DE PROTEÇÃO À SAÚDE E O DEVER DE PROTEÇÃO À LIBERDADE DE COMUNICAÇÃO E INFORMAÇÃO NO CASO DA PROPAGANDA COMERCIAL DE TABACO. EXAME DE CONSTITUCIONALIDADE DA LEI N ${ }^{\circ}$ 9.294/96.
}

\section{A CONSULTA}

\subsection{A Confederação Nacional da Indústria} (CNI) ingressou, em 29.09.04, com Ação Direta de Inconstitucionalidade (ADIN) perante o Supremo Tribunal Federal argüindo a inconstitucionalidade das limitações impostas pela Lei $n^{\circ} 9.294 / 96$ e suas posteriores modificações à publicidade de cigarro por violação a várias normas constitucionais.

1.2. A referida Lei estabelece que a propaganda comercial de produtos fumígeros só poderá ser feita por meio de pôsteres, painéis e cartazes na parte interna dos locais de venda. Além disso, ela exige que a propaganda contenha advertência sobre os malefícios do fumo, indicando frases a serem usadas nas embalagens.

1.3. A autora da Ação Direta de Inconstitucionalidade sustenta a inconstitucionalidade das referidas limitaçōes, pelos seguintes motivos, aqui sintetizados: violação ao princípio da liberdade de informação (art. $5^{\circ}$. XIV) e de comunicação (art. $5^{\circ}$, IV e IX), que seriam inviabilizados pela proibição de propaganda nos veículos de comunicação de massa; violação à regra que permite apenas a criação de meios de defesa para a pessoa e a família se defenderem de propagandas de produtos nocivos à saúde e a regra que estabelece apenas a exigência de advertência sobre os malefícios do fumo, nunca a proibição da propaganda nos veículos de comunicação de massa ou a veiculação de contrapropaganda; a violação ao princípio da legalidade pela delegação ao Poder Executivo de poderes reservados ao Poder Legislativo: violação desproporcional ao princípio da liberdade de exercício de atividade econômica (art. 170) pelo impedimento de fazer propaganda de produtos lícitos.

1.4. Dentre as várias normas constitucionais violadas está a regra que prevê restrições à publicidade (art. 220), o princípio que garante a liberdade de comunicação (art. $5^{\circ}$, IV e IX) e o princípio que protege a liberdade de informação (art. $5^{\circ}$, XIV).

1.5. Diante dos graves efeitos que podem advir da decisão do Supremo Tribunal Federal e da multiplicidade de posições existentes sobre o caso, a Associação Nacional de Jornais - ANJ honra-me com a solicitação de Parecer a respeito da inconstitucionalidade da Lei $n^{\circ} 9.294 / 96$, que passo a emitir.

\section{2 - O PARECER}

\subsection{PRESSUPOSTOS DE ANÁLISE}

2.1.1. Tendo em vista a multiplicidade de modos de análise do conflito entre o dever de proteger a liberdade de comunicação e de in- 
formação e o dever de proteger a saúde, é preciso, antes de tudo, fixar os pressupostos de análise do caso.

2.1.2. O controle a ser feito pelo Supremo Tribunal Federal envolve um problema de Direito Constitucional Brasileiro. Vale dizer, para saber como resolver o conflito entre o dever de proteger a saúde e o dever de proteger a liberdade de comunicação e informação é preciso verificar como a Constituição da República Federativa do Brasil de 1988 trata da matéria. É necessário, desde o início até o fim, estabelecer uma relação de respeito à Constituição, como, aliás, preconiza o próprio Supremo Tribunal Federal, do modo seguinte:

"A defesa da Constituição não se expõe, nem deve submeter-se, a qualquer juízo de oportunidade ou de conveniência, muito menos a avaliações discricionárias fundadas em razões de pragmatismo governamental. A relação do Poder e de seus agentes, com a Constituição, há de ser, necessariamente, uma relação de respeito."।

2.1.3. A necessidade de defesa da Constituição traz quatro conseqüências da mais alta relevância para o caso em pauta. Primeiro, leva ao afastamento da mera transposição, para a solução do caso, de interpretações obtidas pela doutrina estrangeira com base noutras constituições, por mais interessantes que elas possam ser. Isso não quer dizer que as reflexões advindas do Direito Comparado, ou mesmo estrangeiro, não possam ser úteis para suportar essa ou aquela interpretação do Direito Constitucional Brasileiro. Muito menos quer dizer que a utilização de estudos estrangeiros sobre Teoria Geral do Direito - o que é feito, diga-se de passagem, neste Parecer não sejam absolutamente imprescindíveis para a correta interpretação constitucional. $O$ que essas reflexões não podem é implicar, de um lado, na desconsideração das particularidades da Constituição da República Federativa do Brasil de 1988 e, de outro, na falta de atenção à incompatibilidade das soluções es- trangeiras com a solução efetivamente adotada no Brasil. Se o poder público pode restringir a publicidade noutros países, desse ou daquele modo e com essa ou aquela intensidade. não quer dizer que também possa fazê-lo do mesmo modo e com a mesma intensidade no Brasil.

2.1.4. É preciso, a qualquer custo, preservar o império da Constituição e os princípios por ela positivados, como exige o Supremo Tri. bunal Federal:

"Argumentos de necessidade, por mais relevantes que possam ser, näo devem prevale. cer sobre o império da Constituição. Razóes de Estado, ainda que vinculadas a motivos de elevado interesse social, náo podem legitimar o desrespeito e a afronta a principios e valo. res sobre os quais tem assento o nosso sistema de direito constitucional positivo."?

2.1.5. Essa precaução inicial é relevante. pois a análise das restrições à propaganda de tabaco é feita, nas mais das vezes, com base, exclusiva ou preponderante, em estudos elaborados a respeito da Grundgesetz für die Bundesrepublik Deutschland, da Constituição da República Portuguesa ou da The United States Constitution, ficando a referibilidade à Constituição da República Federativa do Brasil de 1988 cada vez menos intensa, quando referibilidade alguma ainda resta.

2.1.6. Segundo, conduz à inconsistência de interpretações obtidas pela mera consideração de modelos ideais de Estado ou de sociedade que não encontram suporte na Constituição da República Federativa do Brasil de 1988. Isso não quer dizer que as ponderações advindas da Teoria do Estado não possam ser úteis para justificar essa ou aquela interpretação do Direito Constitucional Brasileiro. O que essas reflexões não podem é implicar na sobreposição de um modelo teórico ideal ao modelo efetivamente adotado pela Constituição da República Federativa do Brasil de 1988. Essa exigência foi lembrada pelo próprio Supremo

1 Ação Direta de Inconstitucionalidade $\mathrm{n}^{\circ}$ 2010-MC, Relator Ministro Celso de Mello, DJ 12.04.02.

2 Supremo Tribunal Federal, Tribunal Pleno, Recurso Extraordinário $n^{\circ} 150.764$, Relator Ministro Sepúlveda Pertence, 16.12.92. 
Tribunal Federal, quando analisou o princípio federativo, da seguinte forma:

"1. A 'forma federativa de Estado' - elevado a princípio intangível por todas as Constituições da República - não pode ser conceituada a partir de um modelo ideal e apriorístico de Federação, mas, sim, daquele que o constituinte originário concretamente adotou e, como o adotou, erigiu em limite material imposto às futuras emendas à Constituição..."'

2.1.7. Essa cautela antecipada é necessária, pois a análise das restrições à propaganda de tabaco é normalmente empreendida com base, exclusiva ou preponderante, em modelos ideais de Estado ("Estado Social", "Estado Pós-Social", "Estado Cooperativo", "Estado Protetivo") ou de sociedade ("sociedade de informação", "sociedade pluralista", "sociedade de risco"), ficando o modelo de Estado efetivamente adotado pela Constituição da República Federativa do Brasil de 1988 no plano secundário, quando lhe é reservado algum plano.

2.1.8. Terceiro, leva à impropriedade de interpretações obtidas por meio da desconsideração das técnicas normativas utilizadas pela Constituição da República Federativa do Brasil de 1988. Como a instituição de princípios conduz a consequiências argumentativas diversas daquelas presentes no caso da positivação de regras, a falta de atenção ao modo mediante o qual as limitações à publicidade do tabaco foram constitucionalmente estabelecidas conduz o intérprete a ponderar externa e horizontalmente princípios quando o correto seria a ponderação interna e vertical de uma regra e vice-versa.

2.1.9. Essa ressalva introdutória é essencial, pois o exame das restrições à propaganda de tabaco é normalmente levado a cabo por meio de uma livre ponderação entre as finalidades estatais e os direitos fundamentais individuais sob o critério da proporcionalidade, com des- consideração das regras específicas aplicáveis ao caso.

2.1.10. Quarto, leva à incoerência de interpretações obtidas por meio do desprezo da linguagem normativa usada pela Constituição da República Federativa do Brasil de 1988. Como a escolha dessa ou daquela expressão provoca efeitos que restringem a liberdade do intérprete, a falta de análise da linguagem usada para permitir restrições legais à publicidade do tabaco faz com que o intérprete desconsidere conceitos cujas propriedades são conotadas, direta ou indiretamente, pelo ordenamento constitucional. Essa exigência foi registrada pelo próprio Supremo Tribunal Federal, quando analisou os limites para a instituição do imposto sobre a renda, do seguinte modo:

"Concordo em que a lei pode, casuisticamente, dizer o que é ou o que não é renda tributável. Mas não deve ir além dos limites semânticos, que são intransponíveis".?

2.1.11. Essa reserva inicial é relevante, pois o exame das restrições à propaganda de tabaco é normalmente feito como se a escolha dessa ou daquela palavra ou expressão pelo Poder Constituinte Originário não tivesse conseqüência significativa alguma. $E$ isso não pode ser aceito, como preconizado pelo Supremo Tribunal Federal:

"O conteúdo político de uma Constituição não é conducente ao desprezo do conteúdo vernacular das palavras, muito menos ao do técnico, considerados os institutos consagrados pelo Direito." 3

2.1.12. Com a consideração desses pressupostos metodológicos pretende-se demonstrar que o caso das limitações à propaganda de tabaco, ao contrário do que se normalmente crê, é um caso fácil de ponderação interna de regras de competência e, não, um caso difícil de ponderação livre de princípios. ${ }^{\star}$

\section{Ação Direta de Inconstitucionalidade. Relator Ministro Sepúlveda Pentence. DJ 01.12.2000.}

2 Recurso Extraordinário $n^{\circ}$ 71.758, Relator Ministro Thompson Flores, RTJ 66. p. 150.

3 Supremo Tribunal Federal, Tribunal Pleno, Recurso Extraordinário $n^{\circ}$ 166.772-9-RS, Relator Ministro Marco Aurélio. DOU 12.05.94. 


\subsection{AS TÉCNICAS NORMATIVAS UTIILIZÁ VEIS E SUAS CONSEQÜENNCIAS \\ ARGUMENTATIVAS EM GERAL}

\subsubsection{A INSTITUIÇÃO DE PRINCÍPIOS E SEUS EFEITOS}

\subsubsection{CONCEITO DE PRINCÍPIOS}

\subsection{Há duas grandes formas de regu-} lar a conduta humana: de um lado. por meio do estabelecimento de princípios: de outro. mediante a instituição de regras. Como são técnicas normativas diferentes. a escolha de uma delas, em detrimento da outra, altera substancialmente a argumentaçào a ser utilizada no ato de interpretação e de aplicação.

2.2.1.1.2. Deixando de lado as divergências doutrinárias em relação à definição de princípios, pode-se dizer que há concordância no sentido de que os princípios preservam valores e impõem a realização de determinados fins, sem, porém, estabelecer o meio como esses valores e esses fins devem ser promovidos.'

2.2.1.1.3. O importante, nesse quadro, é que os princípios, ao contrário das regras, não prescrevem o comportamento a ser adotado, nem delimitam estritamente o âmbito de po- der que poderá ser exercido. Essa característica principal, ao lado de outras, revela que os princípios têm algumas qualidades particulares cuja investigação é de extrema importância para o caso em pauta.

\subsubsection{EFEITOS DIRETOS DOS PRINCÍPIOS}

\subsection{AUSÊNCIA DE ESCOLHA DO MEIO DE ATUAÇÃO DO PODER PÚBLICO}

2.2.1.2.1.1. Em primeiro lugar. os principios descrevem um estado de coisas a ser buscado, sem, no entanto, definir previamente o meio cuja adoção produzirá efeitos que contribuirão para promove-lo. Essa nota característica dos princípios foi bem notada por ALEXANDER e SHERWIN:

"No caso de um standard, o papel da Lex (ou da Super Lex) é o de identificar fins $e$ valores a serem perseguidos, ao mesmo tem. po em que diz muito pouco sobre os meios de persegui-los." 2

2.2.1.2.1.2. Uma norma que protege a liberdade de comunicação, sem definir o modo como essa liberdade será buscada, é um princípio. Isso porque, embora defina o fim a ser buscado, a norma deixa aberta a escolha do meio para o aplicador.

5 SCHAUER. Frederick. Easy Cases. Modern Constitucional Theory: a Reader. 5. ed. Org. John Garvey. Alexander Aleinikoff e Daniel Farber. St. Paulo: West, 2004. p. 130.

1 ÁVILA. Humberto. Teoria dos princípios. 4. ed. 2. tir. São Paulo: Matheiros. 2005 p. 70. ESSER. Josef. Grundsatz und Norm in der richterlichen Fortbildung des Privatrechts. 4. imp. Tübingen: Mohr Siebeck. 1990. p. 51. LARENZ. Karl. Richtiges Recht. München: Beck. 1979. p. 26. CANARIS, ClausWilhelm. Systemdenken und Systembegriff in der Jurisprudenz. Berlin: Duncker und Humblot, 1983. pp. 50. 53 e 55. DWORKIN. Ronald. The Model of Rules. University of Chicago Law Review 35 (1967), p. 14 e ss. ALEXY, Robert. Zum Begriff des Rechtsprinzips. Rechtstheorie Beiheft I (1979). p. 59 e ss. Idem. Rechi, Vernunft, Diskurs. Frankfurt: Suhrkamp, 1995. p. 177. Idem. Rechtsregeln und Rechtsprinzipien. Archives für Rechts und Sozialphilosophie. 25 (1985), p. 19 e ss. Idem. Rechtssystem und praktische Vernunft. Recht, Vernunft. Diskurs. Frankfurt: Suhrkamp, 1995. p. 216-217. Idem. Theorie der Grundrechte. 2. ed. Frankfurt: Suhrkamp. 1994. p. 77 e ss.

2 ALEXANDER, Larry e SHERWIN, Emily. The Rules of Rules - Morality, Rules and the Dilemmas of Law. Durham e Londres: Duke University Press, 2001. p. 103. 


\subsection{FALTA DE PRODUÇÃO DE UMA SOLUÇÃO PARA O CONFLITO ENTRE PRINCÍPIOS}

2.2.1.2.2.1. Em segundo lugar, os princípios, justamente porque apenas apontam para finalidades a serem buscadas, normatizam uma parte da controvérsia e necessitam da complementação de outros princípios no processo de aplicação. Precisamente por isso, a decisão deverá ser tomada por meio da ponderação quantitativa entre os princípios concretamente colidentes. Essa outra qualidade também foi notada por ALEXANDER e SHERWIN:

"Em outras palavras, aquele que faz a Lex não está buscando uma completa solução para a controvérsia." I

2.2.1.2.2.2. Isso ocorre porque os princípios, ao deixarem aberta a escolha dos meios a serem escolhidos para sua promoção, não trazem uma solução para o conflito de interesses que pode surgir no processo de aplicação.

\subsubsection{EFEITOS INDIRETOS DOS PRINCÍPIOS}

\subsection{INCLUSÃO DE RAZÕES NA INTERPRETAÇÃO}

2.2.1.3.1.1. Os princípios, devido ao seu caráter complementar, incluem, no processo de aplicação, as razões que devem ser consideradas diante do conflito.

2.2.1.3.1.2. O aplicador, em vez de ter impedida ou restringida sua atividade de investigar as razões morais que estão por trás das normas, está livre para ponderá-las diretamente umas com as outras.

\subsection{AUSÊNCIA DE VINCULAÇÃO ESTRUTURAL E DEFINITÓRIA}

2.2.1.3.2.1. E, finalmente, porque os princípios não estabelecem, de antemão, o meio de atuação do poder público, eles deixam de vincular o aplicador a uma operação de correspondência entre o conceito da hipótese normativa e o conceito dos fatos do caso.

2.2.1.3.2.2. Ao invés disso, o aplicador está incumbido de fazer uma ponderação concretamente orientada entre os princípios conflitantes, ele próprio encontrando os meios adequados, necessários e proporcionais à consecução do fim cuja realização é determinada pela positivação dos princípios.

\subsubsection{A INSTITUIÇÃO DE REGRAS E SEUS EFEITOS}

\subsubsection{CONCEITO DE REGRAS}

2.2.2.1.1. As regras são normas imediatamente descritivas, primariamente retrospectivas e com pretensão de decidibilidade e abrangência, para cuja aplicação se exige a avaliação da correspondência. sempre centrada na finalidade que thes dá suporte ou nos princípios que thes são axiologicamente sobrejacentes, entre a construção conceitual da descrição normativa e a construção conceitual dos fatos. ${ }^{2}$ As regras, portanto, possuem algumas características peculiares cuja análise interessa mais de perto para o caso em pauta.

1 ALEXANDER, Larry e SHERWIN, Emily. The Rules of Rules - Morality. Rules and the Dilemmas of Law. Durham e Londres: Duke University Press, 2001. p. 103.

2 ÁVILA, Humberto. Teoria dos princípios. 4. ed. 2. tir. São Paulo: Malheiros, 2005. p. 70. 


\subsubsection{EFEITOS DIRETOS DAS REGRAS}

\subsection{ESCOLHA DO MEIO DE ATUAÇÃO DO PODER PÚBLICO}

2.2.2.2.1.1. Em primeiro lugar, as regras descrevem a conduta a ser adotada ou a parcela de poder a ser exercida pelo seu destinatário. Uma norma que, em vez de se limitar a proteger a saúde, vai além e define o modo como essa proteção será buscada, é uma regra. Isso porque ela não deixa aberta a escolha de qualquer meio de atuação do destinatário, definindo, em vez disso, um meio específico.

2.2.2.2.1.2. A escolha de um meio específico de atuação do poder público por meio da positivação de uma regra faz com que o Poder Legislativo ou o Poder Executivo não fique livre para escolher outro meio, por melhor que lhe possa parecer. Quando há uma regra, portanto, o conflito moral que surgiria, caso não houvesse sido editada a regra, deixa de surgir pelo efeito decisório da regra que foi editada. Daí a afirmação de ALEXANDER e SHERWIN: "Regras prestam-se a estabelecer o que deve ser feito por meio do afastamento de considerações morais."' No mesmo sentido, as palavras de GOTTLIEB:

"Regras são destinadas a conferir o poder de decidir, bem como a controlar a discricionariedade. Com regras, ao invés de uma caixa opaca indefinida, os juizes têm uma série de instruçōes que podem ser razoavelmente bem descritas e que podem ser aplicadas de uma forma suficientemente clara..."."

\subsection{PRODUÇÃO DE UMA SOLUÇÃO PARA O CONFLITO ENTRE RAZÕES}

2.2.2.2.2.1. Em segundo lugar, as regras, ponderando previamente todos aspectos relevantes sobre o conflito entre princípios, pretendem estabelecer uma decisão para esse conflito. Desse modo, elas geram "uma solução específica para o conflito entre razões". Isto é, tendo sido editada uma regra que estabelece uma decisão específica para um conflito entre princípios, não pode o Poder Legislativo ou o Poder Executivo ponderar novamente os princípios em conflito tomando outra decisão. Daí se dizer que as regras são indiferentes (ou, no mínimo, resistentes) às razões que visam a harmonizar. Assim ALEXANDER e SHERWIN: "Elas (as regras) são opacas aos princípios morais que devem efetuar". 4

2.2.2.2.2.2. De fato, as regras têm a função de gerar uma solução para um conflito, evitando que a controvérsia entre os valores morais que elas afastam ressurja no momento de aplicação. $\mathrm{O}$ próprio Poder Constituinte faz uma ponderação anterior que afasta a ponderação horizontal posterior.

\subsubsection{EFEITOS INDIRETOS DAS REGRAS}

\subsection{EXCLUSÃO DE RAZÕES NA INTERPRETAÇÃO}

2.2.2.3.1.1. As regras, devido ao seu caráter decisório, excluem razões que seriam consideradas não houvesse sido escolhida a técnica

1 ALEXANDER, Larry e SHERWIN, Emily. The Rules of Rules - Morality, Rules and the Dilemmas of Law. Durham e Londres: Duke University Press, 2001. p. 4.

2 GOTTLIEB, Stephen E.. The Paradox of Balancing Significant Interests. Hastings Law Journal. v. 45, n. 4, abr./1994, p. 843.

3 ÁVILA, Humberto. Teoria dos princípios. 4. ed. 2. tir. São Paulo: Malheiros, 2005. p. 68.

4 ALEXANDER, Larry e SHERWIN. Emily. The Rules of Rules - Morality, Rules and the Dilemmas of Law. Durham e Londres: Duke University Press, 2001. p. 30. 
de normatização por meio da regra. Vale dizer, se não existisse a regra, o intérprete estaria liberado para decidir a questão levando em conta outras razões, mas como há uma regra posta, essas razões ficam excluídas pela razão imposta pela regra. Daí se dizer que as regras estabelecem razões de segunda ordem que bloqueiam a ação de razões de primeira ordem.' Ou nas palavras de RAZ:

"Primeiramente, razóes excludentes excluem pela espécie e não pelo peso. Elas podem excluir todas as razões de uma certa espécie (como, por exemplo, considerações sobre ajuda econômica), que incluem razóes muito relevantes, ao mesmo tempo em que podem não excluir considerações até triviais, mas pertencentes a outra espécie (como, por exemplo, considerações sobre a honra). (...) O seu impacto não é no sentido de alterar a ponderação das razões, mas de excluir a ação na ponderação das razões. "?

2.2.2.3.1.2. O importante é que todas aquelas razões que seriam consideradas têm sua consideração bloqueada pela instituição da regra, que passa a ser a própria razão de decidir. Nesse sentido, SCHAUER:

"As regras bloqueiam a apreciação do conjunto de razões que sustentam uma decisão particular de dois modos diferentes. Em primeiro lugar, elas excluem da apreciação razões que poderiam estar disponíveis, caso o julgador não tivesse sido compelido por uma regra. Em segundo lugar, a própria regra se torna uma razão para agir, ou uma razão para decidir." 3

2.2.2.3.1.3. Essa eficácia bloqueadora, na interpretação constitucional, também foi bem apreendida por PILDES, nos seguintes termos:
"O enfoque das 'razões excluidas' sobre o direito constitucional envolve um método distinto de se compreender a tomada de decisão judicial. Quando os tribunais aplicam este enfoque explicitamente ou, de forma mais comum, implicitamente, eles näo ponderam direitos individuais em face de interesses esta. tais. Colocando-se de lado a retórica judicial. o processo não é aquele quantitativo pretendido, no qual se atribuem pesos a essas entidades incomensuráveis. Definir razões excluidas é, ao contrário, uma tarefa qualitativa que exige dos tribunais uma avaliação das justificativas para a ação pública em contrariedade com os principios que concedem às diferentes esferas a sua estrutura normativa única." 4

\subsection{VINCULAÇÃO ESTRUTURAL}

2.2.2.3.2.1. Essas características das regras têm uma importância sem igual para a interpretação constitucional, já que elas modificam o próprio processo de resolução dos conflitos constitucionais, o que nem sempre é lembrado pelos juristas, como observa PILDES:

"Causa surpresa descobrir quantos conflitos constitucionais são resolvidos de forma mais clara por meio deste processo argumentativo. Muitos casos que parecem exigir a ponderação de direitos individuais em face de interesses estatais revelam-se, ao contrário, demandando, de uma forma mais simples, a definição de razões excluídas. A melhor explicação para estes casos é a de que os tribunais de hoje, como seus pares no final do século XIX, estão precipuamente interpre-

1 RAZ, Joseph. The Authority of Law - Essays on Law and Morality. Oxford: Clarendon Press, 2002. p. 17.

2 RAZ. Joseph. The Authority of Law - Essays on Law and Morality. Oxford: Clarendon Press. 2002. p. 22-23.

3 SCHAUER, Frederick. Formalism. The Yale Law Journal. v. 97, n. 4, mar./1988, p. 537.

4 PILDES. Richard H.. Avoiding Balancing: The Role of Exclusionary Reasons in Constitutional Law. Hastings Law Journal. v. 45, n. 4, abr./1994, p. 750. 
tando a lógica constitucional que define as fronteiras entre as distintas esferas de poder político. Quando este método está em operação, o problema da ponderação se dissolve." 1

2.2.2.3.2.2. Nesses casos, a legitimidade do poder não é descoberta por meio da ponderação quantitativa entre o interesse estatal e o interesse individual, no sentido de que será admitida uma restrição tanto maior ao direito individual, quanto mais importante for a finalidade estatal perseguida; em vez disso, a legitimidade do poder é averiguada por meio de uma análise qualitativa que investiga a estrutura do poder que é atribuído por meio de uma regra. Assim PILDES. quando se refere ao método qualitativo ou estrutural de interpretação das regras em comparação com o método qualitativo ou ponderativo de interpretação dos princípios:

"Mas, uma lez adotada a concepção estrutural dos direitos, o foco não é no quantum de dano individualizado envolvido, mas, antes, nas justificativas qualitativas para o exercício do poder pelo Estado."2

"A diferença entre esses paradigmas de direitos alternativos - um individualista, o outro estrutural - tem implicações significantes para o direito constitucional, incluindo aí o problema da ponderação. Sob a concepção individualista de direitos, os tribunais 'ponderam' o peso dos danos individualizados $e$ a força/solidez dos interesses estatais legitimos. Sob a concepção estrutural, os tribunais avaliam as razões para a ação estatal em diferentes esferas. A perspectiva estrutural conscientemente reconhece que os tribunais não estão envolvidos com um exercício aparentemente quantitativo, mas com uma tarefa interpretativa de definir princípios de ação estatal permitidos pela Constituição em várias esferas."

2.2.2.3.2.3. Essas considerações têm uma relevância capital para a interpretação constitucional, já que, presente uma regra específica sobre a controvérsia, a interpretação deixa de ser baseada na ponderação livre e horizontal para centrar-se na ponderação interna da própria hipótese da regra. Nesse sentido, PILDES:

"Se, ao invés, nós nos concentrarmos no papel central das 'razões excluidas', o direito constitucional será muito menos uma questão direitos versus interesses estatais e muito mais uma questão de definição das fronteiras do poder político em diferentes áreas." 4

\subsection{VINCULAÇÃO DEFINITÓRIA}

2.2.2.3.3.1. É preciso, por fim, chamar a atenção para o fato de que o caráter descritivo das regras, inicialmente examinado, traz repercussões com relação à análise da linguagem estabelecida pela Constituição Federal. Como mencionado, a escolha das regras estabelece âmbitos de competência muito diversos daqueles porventura existentes no caso da instituição de princípios: enquanto nessa hipótese o Poder Legislativo pode escolher os meios para promover os fins, naquela outra ele está previamente vinculado ao meio constitucionalmente escolhido. Isso porque as regras têm caráter imediatamente descritivo de conduta ou de atribuição de poder para a adoção de conduta, cabendo ao intérprete aplicar a regra cujo conceito seja finalmente-correspondente ao conceito dos fatos. ${ }^{5}$

I PILDES, Richard H.. Avoiding Balancing: The Role of Exclusionary Reasons in Constitutional Law. Hastings Law Journal. v. 45, n. 4, abr./1994, p. 714.

2 PILDES, Richard H.. Avoiding Balancing: The Role of Exclusionary Reasons in Constitutional Law. Hastings Law Journal. v. 45. n. 4, abr./1994, p. 729.

3 PILDES, Richard H.. Avoiding Balancing: The Role of Exclusionary Reasons in Constitutional Law. Hastings Law Journal. v. 45, n. 4, abr./1994, p. 724-725.

4 PILDES, Richard H.. Avoiding Balancing: The Role of Exclusionary Reasons in Constitutional Law. Hastings Law Journal. v. 45, n. 4, abr./1994, p. 715. 
2.2.2.3.3.2. O importante, nesse aspecto, é que as regras constitucionais que atribuem ou limitam a competência do Poder Público, quando utilizam palavras específicas, como "comunicação social", "propaganda comercial", "advertência", estabelecem conceitos. cujos núcleos de significado não podem ser desprezados pelo intérprete, nem mesmo a pretexto de prestigiar algum valor constitucional, supostamente de maior hierarquia.

2.2.2.3.3.3. A previsão de conceitos constitucionais pode ser feita de duas formas. De um lado, de modo direto, nos casos em que a Constituição já enuncia expressamente as propriedades conotadas pelos conceitos que utiliza. De outro, de modo indireto, nas situações em que o poder constituinte, ao escolher expressões cujas propriedades já eram conotadas em conceitos elaborados pelo legislador infraconstitucional à época da promulgação da Constituição, opta por incorporá-los ao ordenamento constitucional. Em qualquer dessas hipóteses, a Constituição fixa balizas que não podem ser ultrapassadas pelo legislador ordinário sob a sua vigência.

2.2.2.3.3.4. É verdade que a linguagem é largamente indeterminada. Do fato, porém, que a linguagem é indeterminada não segue nem que ela não possui núcleos de determinação, nem que ela seja totalmente indeterminada e, por isso, supérflua.' Isso significa, em outras palavras, que, mesmo sendo a linguagem indeterminada, não quer dizer que ela não tenha núcleos de significação nem que não possa sofrer determinação pelo uso ou pelo próprio sistema no qual esteja inserida.

2.2.2.3.3.5. Tanto é assim, que o Supremo Tribunal Federal tem uma longa tradição jurisprudencial que reconhece, à linguagem utilizada pela Constituição Federal, núcleos conceituais de significação que não podem ser desprezados pelo intérprete. A essa conclusão pode-se chegar, por exemplo, por meio da análise da jurisprudência sobre conceitos uti- lizados por regras constitucionais de competência.

2.2.2.3.3.6. Com efeito, a jurisprudência sobre conceitos utilizados por regras de competência é sólida no sentido de que a Constituição Brasileira prevê ou incorpora conceitos prévios. Dentre os numerosos acórdãos que poderiam ser aqui mencionados, alguns podem ser destacados.

2.2.2.3.3.7. O Tribunal Pleno do Supremo Tribunal Federal, no Recurso Extraordinário $n^{\circ}$ 203.075-9 (DJ 29.10.99), cujo Relator foi o Ministro Maurício Corrêa, ao analisar a instituição do imposto sobre circulação de mercadorias no caso de importação de mercadorias por pessoa física, pressupôs um conceito constitucional de circulação de mercadoria, como bem esclarece o voto do Ministro Relator:

"No ponto, o termo operação exsurge na acep̧̧ão de ato mercantil; o vocábulo circu. lação é empregado no sentido jurídico de mudança de titularidade e não de simples movimentação física do bem, e à expressāo mercadoria é atribuida a designação genérica de coisa móvel que possa ser objeto de comércio por quem exerce mercancia com freqüencia e habitualidade" (voto do Relator, p. 402)

2.2.2.3.3.8. O voto do Ministro Marco Aurélio segue, de modo enfático, o mesmo entendimento:

"Costumo dizer que o Estado tudo pode. $O$ Estado legisla, o Estado executa a lei, o Estado julga a aplicação da lei. Que o faça bem $e$, em se tratando de tributo, que se atenha ao figurino constitucional." (p. 406).

2.2.2.3.3.9. O Tribunal Pleno do Supremo Tribunal Federal, no Recurso Extraordinário $n^{\circ}$ 116.121-3 (DJ 25.05.01), cujo Relator foi o Ministro Octávio Gallotti, ao analisar a instituição do imposto sobre serviços relativamente aos contratos de locação, decidiu pela não incidência do referido imposto, porque

5 ÁVILA, Humberto. Teoria dos Princípios. 4. ed. 2. tir. São Paulo: Malheiros, 2004. p. 63.

1 SCHAUER, Frederick. Easy Cases. Modern Constitucional Theory: a Reader. 5. ed. Org. John Garvey, Alexander Aleinikoff e Daniel Farber. St. Paulo: West, 2004. p. 130. 
"na espécie, conforme a própria nomenclatura revela e, portanto, considerado o figurino constitucional, pressupõe a prestação de serviços e não o contrato de locação" (voto do Redator, p. 702). Essa decisão pressupôs um conceito constitucional de prestação de serviços, como bem esclarece o voto do Ministro Redator para o acórdão, Marco Aurélio:

"Em sintese, há de prevalecer a definição de cada instituto, e somente a prestação de serviços, envolvido na via direta o esforço humano, é fato gerador do tributo em comento. Prevalece a ordem natural das coisas cuja força surge insuplantável; prevalecem as balizas constitucionais e legais, a conferirem segurança às relações Estado-contribuinte; prevalece, alfim, a organicidade do próprio Direito, sem a qual tudo será possivel no agasalho dos interesses do Estado, embora não enquadráveis como primários" (voto do Redator, p. 705).

2.2.2.3.3.10. O Tribunal Pleno do Supremo Tribunal Federal, no Recurso Extraordinário $n^{\circ}$ 166.772-9 (DJ 16.12.94), cujo Relator foi o Ministro Marco Aurélio, ao analisar a incidência da contribuição social sobre a folha de salário sobre as remunerações pagas a administradores, avulsos e autônomos, analisou o conceito da expressão "folha de salários", conforme pronunciamento do Ministro Celso de Mello:

"A expressão constitucional 'folha de salários' reveste-se de sentido técnico e possui significado conceitual que não autoriza a sua utilização em desconformidade com a defini. ção, o conteúdo e o alcance adotados pelo Direito do Trabalho" (voto do Ministro Celso de Mello, p. 736).

2.2.2.3.3.11. É importante notar que esse precedente do Supremo Tribunal Federal reformou o acórdão do Tribunal Regional Federal que se recusava a atribuir à expressão folha de salários entendimento técnico, "pois que se trata de dispositivo constitucional que, por sua característica política, escapa aos conceitos pertencentes ao tecnicismo jurídico" (relatório, p. 705). Pois foi justamente o entendimento diametralmente contrário que pre- valeceu no Tribunal Pleno do Supremo Tribunal Federal, conforme se vê no voto do Ministro Celso de Mello:

"As expressões empregados, salários e emprego, Sr. Presidente, refletem noçöes conceituais largamente consolidadas no plano de nossa experiência jurídica. Desse modo, e não obstante o sentido comum que se lhes possa atribuir, esses conceitos encerram car. ga semiológica que encontra, no discurso normativo utilizado pelo legislador constituinte, plena correspondência com o seu exato, técnico e jurídico significado, do qual não pode o legislador ordinário divorciar-se ao veicular a disciplina de qualquer espécie tributária, sob pena de transgredir o comando inscrito no art. 110 do Código Tributário Nacional..." (p. 739).

2.2.2.3.3.12. O exame atento dessas decisões demonstra que os precedentes do Supremo Tribunal Federal säo firmes e reiterados no sentido de que as regras constitucionais atributivas de competência, quando utilizam expressões cujas propriedades sejam conotadas pela própria Constituição ou pela legislação infraconstitucional vigente à época de sua promulgação, prevêem ou incorporam conceitos que fixam balizas intransponíveis ao legislador infraconstitucional. Nesse sentido, não há espaço para entender essas normas como constitucionalmente abertas, assim compreendidas aquelas normas que admitiriam a sua ilimitada ou ampla concretização pelo legislador sem fixação conceitual prévia indisponível. Bem ao contrário, a jurisprudência reiterada do Supremo Tribunal Federal faz referência tanto a "balizas constitucionais" que não podem ser ultrapassadas pelo legislador quanto a "figurinos" e a "conceitos" que o legislador não poderá desprezar.

2.2.2.3.3.13. Entendimento no sentido de que a Constituição não institui nem incorpora conceitos, implica tornar inócua a utilização de expressões pelo poder constituinte, pois elas poderiam ter qualquer conteúdo diverso daqueles correntemente usados pela comunidade jurídica. Mais do que isso: entender que a utilização de expressões não importaria na instituição ou incorporação de sentidos nor- 
mativos seria.compreender a Constituição como um agrupamento de marcas de tinta sem significação alguma. Pior ainda: seria aceitar que não há sentidos normativos prévios que pudessem vincular o legislador. Esse entendimento desafia a força normativa da Constituição, porque a enxerga oca, só com diagramas, mas sem normas; porque a coloca não como realidade normativa ativa e ordenadora, mas como realidade normativa passiva e ordenada, invertendo o eixo normativo do constitucionalismo para o do legalismo; e porque, enfim, transforma o poder constituído no próprio Poder Constituinte.'

\subsubsection{JUSTIFICATIVA PARA A ADOÇÃO DE REGRAS}

2.2.2.4.1. As regras têm a função de pré-decidir o meio de exercício do poder, afastando a incerteza que surgiria não tivesse sido feita essa escolha. É justamente para evitar o surgimento de um conflito moral e para afastar a incerteza decorrente da falta de resolução desse mesmo conflito que o Poder Legislativo opta pela edição de uma regra. Nesse sentido ALEXANDER e SHERWIN:

"A finalidade de se ter a Lei promulgando regras para estabelecer questōes sobre como os princípios morais se aplicam em casos concretos reside na eliminação da controvérsia e da incerteza, e dos custos morais a elas associados." 2

2.2.2.4.2. Além de afastar a controvérsia e a incerteza, a opção pelas regras tem a finalidade de eliminar ou reduzir a arbitrariedade que pode potencialmente surgir no caso de aplicação direta de valores morais. Essa ca- racterística foi assim notada por SCHAUER, ao analisar a importância da qualidade resolutiva das regras para restringir a discricionariedade:

"Em suma, é verdade notória que as regras se atravessam no caminho; mas isto não precisa ser sempre considerado algo ruim. Pode consistir em uma desvantagem quando surge no caminho dos sábios julgadores que ao perseguirem de forma precisa o bem, intuitivamente levam em consideração todos os fatores relevantes. Entretanto, também pode ser uma qualidade, quando surge para restringir julgadores desavisados, incompetentes, de má índole, ávidos por poder, ou simplesmente equivocados, cujo proprio senso de bem diverge daquele do sistema ao qual eles servem." 3

\subsection{No mesmo sentido, SHEPPARD} salienta a importância das regras na redução de arbitrariedades potenciais no manuseio dos princípios:

"Nas mãos de um mercador honesto, a balança é um instrumento para finas comparações de legitimo valor. Utilizada por um mercador corrupto, entretanto, a balança é uma ferramenta de engodo, uma escala em que a verdade é pesada contra o ouro ou o pudding contra a aprovação." 4

2.2.2.4.4. Isso tudo porque, deixando aberta a decisão para que o Poder Legislativo ou o Poder Executivo, de acordo com considerações equiltativas que julgar mais adequadas, possa decidir o caso, corre-se um risco de arbitrariedade, como complementa SCHAUER:

"Talvez o mais importante ao explicar a legalização da eqüidade, entretanto, seja a preocupação recorrente com a potencial arbi-

1 ÁVILA, Humberto. Contribuição Social sobre o Faturamento. Cofins. Base de Cálculo. Distinção entre Receita e Faturamento. Jurisprudência do Supremo Tribunal Federal. Revista Dialética de Direito Tributário (107): 95-109. São Paulo: Dialética, 2004.

2 ALEXANDER, Larry e SHERWIN, Emily. The Rules of Rules - Morality, Rules and the Dilemmas of Law. Durham e Londres: Duke University Press, 2001. p. 30-31.

3 SCHAUER, Frederick. Formalism. The Yale Law Journal. v. 97, n. 4. mar./1988, p. 543.

4 SHEPPARD, Steve. The State Interest in the Good Citizen: Constitutional Balance Between the Citizen and the Perfectionist State. Hastings Law Journal. v. 45, n. 4, abr./1994, p. 971. 
trariedade e a natureza imprevisível do poder eqüitativo, independentemente de quem o exercite."

2.2.2.4.5. O Supremo Tribunal Federal segue esse entendimento e tem decidido pela inconstitucionalidade de restrições à atividade dos particulares em virtude do seu conteúdo arbitrário, da seguinte forma:

"Na hipótese, a matéria, como lembrado. foi regulada pelo Decreto $n^{\circ} 17.727 / 81$, deixando, além disso, inaceitável margem de arbítrio para a aplicação pela autoridade fiscal".2

2.2.2.4.6. Para o caso em pauta, essas considerações demonstram que a opção pelas regras tem a finalidade de evitar que o Poder Legislativo ou Executivo fique encarregado de tomar uma decisão caso a caso, pois, se isso for feito, corre-se o risco de que a prática termine restringindo desmedidamente os princípios da liberdade de comunicação e de informação.

\subsubsection{O CONFLITO ENTRE PRINCÍPIOS E REGRAS}

2.2.3.1. Mesmo considerando que a Constituição Federal estabelece balizas conceituais quando utiliza expressões específicas, como reiteradamente tem decidido o Supremo Tribunal Federal, ainda assim se poderia pensar que havendo, na mesma Constituição, regras e princípios, como é o caso do princípio da proteção à saúde, poderia ocorrer um dos seguintes fenômenos: ou a prevalência do princípio sobre a regra, atuando aquele diretamente no âmbito não abrangido por esta; ou a ampliação do conceito previsto na regra pela atuação indireta do princípio sobre a sua in- terpretação. Ambos os fenômenos, ainda que conceitualmente separáveis, provocam o mesmo efeito jurídico: criação de uma nova restrição sem atribuição expressa de poder por meio de uma regra. Nenhuma das duas possibilidades, no entanto, pode ser aceita.

2.2.3.2. Isso porque num confronto horizontal entre regras e princípios, as regras devem prevalecer, ao contrário do que faz supor a descrição dos princípios como sendo as normas mais importantes do ordenamento jurídi$\mathrm{co.}^{3}$ De fato, as regras têm uma eficácia que os princípios não têm. ${ }^{\dagger}$ Em primeiro lugar, a eficácia das regras é decisiva, ao passo que a dos princípios é apenas contributiva, não cabendo ao intérprete, por consequiência, afastar. sem mais.a decisão tomada pela Constituição Federal pela sua própria decisão pessoal. Em segundo lugar. as regras têm uma eficácia definitória dos próprios princípios com os quais horizontalmente se relacionam. no sentido de que vários dos ideais cuja realização é por eles determinada já têm seu modo de concretização prévia e abstratamente "delimitado" no plano constitucional, não cabendo ao intérprete concretizar o ideal constitucional de modo diferente daquele já definido pela Constituição por meio de suas regras. A previsão constitucional de princípios ou de instituições correlacionados àquelas regras de competência não invalida a conclusão anterior, na medida em que a previsão de princípios e de instituições deixa livre a adoção dos comportamentos necessários à sua realização, "salvo se o ordenamento jurídico predeterminar o meio por regras de competência". 5

2.2.3.3. Embora não tenha manifestado expressamente esse entendimento, não deixa de ser essa a posição do Supremo Tribunal Fe-

1 SCHAUER, Frederick. Profiles, Probabilities and Stereotypes. Cambridge: Harvard University Press. 2003. p. 53.

2 Recurso Extraordinário $n^{\circ}$ 106.759. Relator Ministro Oscar Corrêa. Decisão em 24.(19.85. Revista Trimestral de Jurisprudência $n^{\circ} 115$. p. 443.

3 Á VILA. Humberto. Teoria dos Princípios. 4. ed. 2. tir. São Paulo: Malheiros. 2004. p. 85.

4 ÁVILA. Humberto. Teoria dos Princípios. 4. ed. 2. tir. São Paulo: Malheiros. 2004. p. 71.82 e 83.

5 ÁVILA. Humberto. Teoria dos Princípios. 4. ed. 2. tir. São Paulo: Malheiros. 2004. p. 71. 
deral na Ação Direta de Inconstitucionalidade $n^{\circ} 815$, por meio da qual um ente federado (Estado do Rio Grande do Sul) arguiiu a inconstitucionalidade de uma regra constitucional, sobre proporcionalidade de representação no Congresso Nacional, em face do próprio princípio federativo. O Tribunal decidiuextinguir a açãopor impossibilidade jurídica do pedido por entender que não poderia afastar, com base num princípio, a concretização definitória escolhida pelo Poder Constituinte Originário por meio das regras constitucionais. Assim, entendeu-se que o Poder Constituinte instituiu o princípio federativo, mas o fez conforme estabelecido na regra prevista no artigo 45, e com as restrições ali estabelecidas. Desta decisão, pode-se concluir que não é permitido a outro Poder rever a "ponderação" realizada pelo próprio Poder Constituinte Originário. Tanto é assim, que o Acórdão menciona, na página 347, que o princípio da igualdade está limitado pela própria Constituição no artigo $5^{\circ}$. inciso I ou que o princípio democrático está limitado pela própria Constituição no artigo $1^{\circ}$ (" ... nos termos desta Constituição"). Do mesmo modo, foi acolhido o parecer da Advocacia Geral da União no sentido de que " a tese defendida pelo autor sobre a possibilidade de existência de disposições inconstitucionais diante de normas tidas como de hierarquia superior não é aceitável" (página 318). Por fim, o Tribunal entendeu que o Poder Constituinte é livre para fixar os limites de um princípio constitucional, já que "quem é livre para fixar um princípio o é também para impor-lhe exceções" (página 325). Essas exceções são estabelecidas por meio de regras. Pode-se afirmar que o Supremo Tribunal Federal, com outras palavras, decidiu que o aplicador, seja ele o Poder Judiciário, seja ele o Poder Legislativo, não pode afastar uma regra com base num princípio constitucional, em razão do caráter defïnitório e decisivo da regras.

2.2.3.4. O mesmo raciocínio foi teito pelo Supremo Tribunal Federal quando analisou a possibilidade de resolver o conflito entre as garantias constitucionais de proteção contra a prova ilícita e o interesse público repressivo. Em vez de efetuar uma ponderação entre os direitos individuais regrados pela Constituição e o interesse público colidente, o Supremo Tribunal Federal decidiu que não cabe a ele efetuar nova ponderação quando a Constituição já fez uma ponderação anterior por meio do estabelecimento de uma regra. Ilustrativo é o voto do Ministro Sepúlveda Pertence:

"Posto não ignore a autoridade do entendimento contrário, resisto, no entanto, a admitir que à garantia constitucional da inadmissibilidade da prova ilícita se possa opor, com o fim de dar-Ihe prevalência em nome do princípio da proporcionalidade. o interesse público na eficácia da repressão penal em geral ou, em particular, na de determinados crimes.

É que. aí. foi a Constituição mesma que ponderou os valores contrapostos e optou em prejuizo, se necessário. da eficácia da persecução criminal - por valores fundamentais, da dignidade humana, aos quais serve de salvaguarda a proscrição da prova ilícita." I

2.2.3.5. Enfim, não é adınissivel afastar. nem ampliar além do limite semântiço intransponível. uma regra constitucional. com base num princípio, por ser a regra a própria solução constitucional para determinado conflito de interesses. Ainda mais considerando que a Constituição Federal não tem apenas um princípio que possa afastar ou ampliar uma determinada regra, mas vários princípios, nem todos apontando numa só direção. Nesse sentido, por exemplo, ao lado do princípio da proteção da saúde, há os princípios da proteção da liberdade de comunicação e de informação e da liberdade de exercício de atividade econômica. Vale dizer, os princípios, na Constituição Federal, não apenas valorizam elementos fáticos ligados à saúde, mas, também, elementos relacionados à liberdade. à segurança e à previsibilidade da atuação do Poder Público segundo o padrão normativo previsto (Estado de Direito, segurança jurídica. legalidade e atribuição de poder por meio de regras de competência).A interpretação 
que se centra exclusivamente na proteção à saúde desconsidera o ordenamento constitucional como um todo. O mesmo ocorre com interpretações que, a pretexto de preservar valores supostamente prevalentes, terminam por afastar regras constitucionais que concretizaram esses mesmos valores.

2.2.3.6. Tendo visto os efeitos da adoção da técnica normativa dos princípios e das regras, é preciso analisar quais os limites que a instituição de normas enfrenta. Isso porque, independente de ser princípio ou ser regra, a instituição de qualquer norma não pode violar o núcleo de direitos fundamentais, como se passa a expor.

\subsubsection{O LIMITE MÁXIMO PARA A INSTITUIÇÃO NORMATIVA}

\subsubsection{O exercício do poder conferido pela} Constituição Federal, independente da técnica normativa que tenha sido utilizada, não poderá restringir excessivamente um direito fundamental. Ao instituir direitos fundamentais, a Constituição reflexamente protege determinados bens jurídicos sem os quais eles não têm eficácia mínima. $\mathrm{O}$ exercício do poder não poderá, portanto, atingir esses bens jurídicos, mesmo que essa restrição tenha sido justificada por uma finalidade estatal constitucionalmente prevista, pois, nesses casos, a restrição do núcleo dos direitos fundamentais se mantém proibida ainda quando possa aumentar a utilidade e a eficiência da realização de uma finalidade pública, por serem esses núcleos incomensuráveis. Nesse sentido, SCHAUER, usando o exemplo da tortura como algo incomensurável e injustificável, por melhor que possa ser o motivo estatal . usado para justificá-la:

"Desta forma, o impedimento à tortura se apresenta como um valor incomensurável com os valores de utilidade e eficiência, cuja maximização é por ele (impedimento) restringida." I

2.2.4.2. À proibição de restringir bens jurídicos essenciais à eficácia mínima de direitos fundamentais dá-se o nome de proibição de excesso. Trata-se, como se pode ver, de uma norma que proíbe a restrição de outras no processo de aplicação, como o direito fundamental ao livre exercício de profissão, o que the confere a qualidade de uma meta-norma, aqui denominada de postulado aplicativo da proibição de excesso. Ela fundamenta-se na idéia de que todos os direitos e princípios fundamentais, ainda que possam ser restringíveis, não podem ser atingidos no seu núcleo essencial, sendo esse núcleo definido como aquela parte do conteúdo de um direito sem a qual ele perde a sua mínima eficácia e, por isso, deixa de ser reconhecível como um direito fundamental.'

Esse limite é reconhecido pelo Supremo Tribunal Federal.

2.2.4.3. Com efeito, a Segunda Turma do Supremo Tribunal Federal decidiu por negar provimento a um Recurso Extraordinário por entender excessiva a majoração do imposto de licença sobre as cabines de banho. A recorrente aduziu que tal imposição poderia lhe cercear uma atividade lícita e. por isso, estaria colidindo com o princípio da liberdade de qualquer profissão (art. $141, \S 14$ da Constituição de 1946). O voto do Ministro Orozimbo Nonato faz referência à decisão da Suprema Corte Americana no sentido de que:

o poder de taxar somente pode ser exercido dentro dos limites que o tornem compativel com a liberdade de trabalho, de comércio e de indústria e com o direito de propriedade". ${ }^{3}$

2.2.4.4. O Supremo Tribunal Federal. analisando a constitucionalidade da majoração do antigo imposto de licença, asseverou:

"A meu ver, porém, faz-se dispensável qual. quer referência expressa nesse sentido, pois

1 SCHAUER, Frederick. Profiles, Probabilities and Stereotypes. Cambridge: Harvard University Press, 2003. p. 125.

2 ÁVILA, Humberto. Teoria dos Princípios. 4. ed. 2. tir. São Paulo: Malheiros, 2004. p. 87 e ss.

3 Recurso Extraordinário n. ${ }^{\circ}$ 18.331/SP. Relator Ministro Orozimbo Nonato. DJ 21.09.1951. 
os próprios dispositivos fundamentais, que asseguram as liberdades individuais, entre os quais se incluiu o exercício de qualquer profissão, comércio e indústria, constituem uma implícita limitação ao poder de tributar do Estado, no concernente à criação de impostos exagerados, vedando, por consequência, que a administração, por meio de tributos excessivos, possa tolher, cercear ou dificultar o pleno exercício dos direitos básicos conferidos ao cidadão".'

2.2.4.5. Noutro caso, a Primeira Turma do Supremo Tribunal Federal reconheceu o direito à cobrança do imposto do selo, mas modificou o entendimento em relação ao valor da multa, considerando-a excessiva relativamente ao direito de propriedade e de liberdade. ${ }^{2}$

2.2.4.6. O Supremo Tribunal Federal tem igualmente considerado inconstitucionais as restrições administrativas que, ainda que não bloqueiem de modo absoluto, certamente embaraçam excessivamente o livre exercício de atividade econômica:

"Penso, porém, que, ao estatuir essa exigência, fato que tenho como certo, visto não haver sido contestado, a autoridade arrecadadora estabeleceu, em verdade, sanção fiscal, que, se não impediu totalmente, bloqueou de modo profundo a atividade profissional lícita do contribuinte, violando, de tal arte, o aludido preceito constitucional, sem falar na violação da Súmula 547". ${ }^{3}$

2.2.4.7. Noutro julgamento, o Plenário do Supremo Tribunal Federal decidiu por deferir medida liminar que suscitava a inconstitucionalidade de Lei Estadual que elevava os valores de taxa judiciária. $O$ fato de a taxa judi- ciária ter sido elevada em $827 \%$ restringiria excessivamente o direito de acesso ao Poder Judiciário a uma grande parcela da população. ${ }^{+}$

2.2.4.8. Noutro caso, o Supremo Tribunal Federal analisou a obrigatoriedade de utilização de balanças especiais por veículos transportadores de botijões de gás. Dentre as várias alegações, uma delas diz respeito à proibição de excesso: os efeitos da utilização do meio poderiam provocar a restrição excessiva do direito fundamental de livre iniciativa (a utilização de balanças poderia levar as empresas "à ruína"). . $^{-}$

2.2.4.9. O Supremo Tribunal Federal também entendeu que submeter o pai presumido ao constrangimento de fazer um exame de DNA para provar a paternidade de um terceiro restringiria excessivamente a dignidade humana. ${ }^{6}$

2.2.4.10. Em todos esses casos, o Supremo Tribunal Federal constatou que nenhuma medida estatal pode: (a) restringir excessivamente um direito fundamental, inviabilizando-o substancialmente, independentemente do seu motivo; (b) cercear, tolher ou dificultar sobremaneira o livre exercício da atividade econômica, ainda que a medida não inviabilize por completo a atividade empresarial.

2.2.4.11. Tendo analisado tanto as técnicas de normatização que podem ser geralmente empregadas por uma constituição (instituição de princípios $\mathrm{x}$ instituição de regras) e as consequiências decorrentes do seu uso (utilização do método quantitativo ou da ponderação externa e horizontal $x$ utilização do método qualitativo, estrutural, definitório ou da pondera-

1 Recurso Extraordinário n 18.976. Relator: Ministro Barros Barreto, ADJ 26.11.52. S. 14653. p. 15 do acórdão, que se refere à decisão recorrida.

2 Recurso Extraordinário n 47.937/Guanabara, Relator: Ministro Cândido Motta, DJ 06.12.62.

3 Recurso Extraordinário ${ }^{\circ}$ 76.455, Relator Ministro Leitão de Abreu, Decisão em 01.04.75, Revista Trimestral de Jurisprudência $\mathrm{n}^{\circ} 73$, p. 825.

4 Representação $n^{\circ}$ 1.077-5/RJ, Relator Ministro Moreira Alves, DJ 26.02.1981.

5 Ação Declaratória de Inconstitucionalidade $n^{\circ}$ 855-2, Relator: Ministro Ministro Sepúlveda Pertence. DJU 01.10.93.

6 Habeas Corpus n 76060-SC, Relator: Ministro Sepúlveda Pertence. DJ 15.05.98, p. 44. 
ção interna ou vertical) quanto os limites da sua instituição, é preciso analisar quais foram as técnicas efetivamente escolhidas pela Constituição da República Federativa do Brasil para resolver o conflito entre o dever de proteger a liberdade de comunicação e de informação e o dever de proteger a saúde no caso da propaganda comercial de tabaco. É o que se passa a examinar.

\subsection{NORMAS APLICÁVEIS AO CASO}

\subsubsection{O caso deste Parecer envolve um con-} flito entre o dever de proteger a liberdade de comunicação e de informação, de um lado. e o dever de proteger a saúde. de outro. Como já enunciado, para saber como resolver essa colisão é preciso verificar como a Constituição da República Federativa do Brasil trata da matéria.

2.3.2. No plano geral, verifica-se que a Constituição Federal tem, de um lado, princípios que suportam a proteção da liberdade de comunicação e de informação, da seguinte forma:

IV - é livre a manifestação do pensamento, sendo vedado o anonimato:

IX - é livre a expressão da atividade intelectual, artística, científica e de comunicação, independentemente de censura ou licença;

XIV - é assegurado a todos o acesso à informação e resguardado o sigilo da fonte, quando necessário ao exercício profissional;

2.3.3. De outro lado, a Constituição Federal também tem um princípio que suporta a proteção da saúde, do seguinte modo:

Art. 196. A saúde é direito de todos e dever do Estado, garantido mediante políticas sociais e econômicas que visem à redução do risco de doença e de outros agravos e ao acesso universal e igualitário às açōes e serviços para sua promoção, proteção e recuperação.

2.3.4. No plano específico, diretamente relacionado com a comunicação social e mais particularmente ainda com a propaganda comercial de tabaco, a Constituição Federal tem dispositivos que geram regras. constantes de capítulo dedicado à "Comunicação Social":
Art. 220. A manifestação do pensamento. ad criação, a expressão e a informação, sob qualquer forma, processo ou veículo não sofrerão qualquer restrição, observado o disposto nesta Constituição.

$\S 1^{\circ}$ - Nenhuma lei conterá dispositivo que possa constituir embaraço à plena liberdade de informação jornalística em qualquer veículo de comunicação social, observado o disposto no art. $5^{\circ}, I V, V, X, X I I I$ e XIV.

$\S 2^{\circ}$ - É vedada toda e qualquer censura de natureza política, ideológica e artística.

$\$ 3^{\circ}$ - Compete à lei federal:

I - regular as diversões e espetáculos públicos, cabendo ao Poder Público informar sobre a natureza deles, as faixas etárias a que não se recomendem, locais e horários em que sua apresentação se mostre inadequada;

II - estabelecer os meios legais que garantam à pessoa e à família a possibilidade de se defenderem de programas ou programaçōes de rádio e televisão que contrariem o disposto no art. 221. bem como da propaganda de produtos, práticas e serviços que possam ser nocivos à saúde e ao meio ambiente.

$\$ 4^{\circ}$ - A propaganda comercial de tabaco, bebidas alcoólicas, agrotóxicos. medicamentos e terapias estará sujeita a restrições legais. nos termos do inciso II do parágrafo anterior, e conterá, sempre que necessário, advertência sobre os malefícios decorrentes de seu uso.

2.3.5. Dentro desse quadro normativo - ou pretensamente dentro dele - o Poder Legislativo editou a Lei $n^{\circ} 9.294 / 96$, criando uma série de restrições à propaganda comercial do tabaco, do seguinte modo:

Art. 3o A propaganda comercial dos produtos referidos no artigo anterior só poderá ser efetuada através de pôsteres, painéis e cartazes, na parte interna dos locais de venda. (Redação dada pela Lei $n^{\circ} 10.167$, de 27.12.2000)

$\S 1$ omissis

\$2 A propaganda conterá, nos meios de comunicação e em função de suas características, advertência escrita e/ou falada sobre os malefícios do fumo. através das seguintes frases, usadas seqüencialmente. de forma simultânea ou rotativa, nesta última hipótese de- 
vendo variar no máximo a cada cinco meses, todas precedidas da afirmação "O Ministério da Saúde Adverte": (Vide Medida Provisória $n^{\circ} 2.190-34$, de 23.8.2001)

I - fumar pode causar doenças do coração e derrame cerebral;

II - fumar pode causar câncer do pulmão, bronquite crônica e enfisema pulmonar;

III - fumar durante a gravidez pode prejudicar o bebê;

IV - quem fuma adoece mais de úlcera do estômago;

$\mathrm{V}$ - evite fumar na presença de crianças;

VI - fumar provoca diversos males à sua saúde.

$\S 3^{\circ} \mathrm{A}$ embalagem. exceto se destinada à exportação, e o material de propaganda referido neste artigo conterão a advertência mencionada no parágrafo anterior. (Redação dada pela Lei $n^{\circ} 10.167$, de 27.12.2000) (Vide Medida Provisória n ${ }^{\circ}$ 2.190-34, de 23.8.2001)

$\$ 4^{\circ}$ Nas embalagens, as cláusulas de advertência a que se refere o $\$ 2$ deste artigo serão seqüencialmente usadas, de forma simultânea ou rotativa. nesta última hipótese devendo variar no máximo a cada cinco meses, inseridas, de forma legível e ostensivamente destacada, em uma das laterais dos maços, carteiras ou pacotes que sejam habitualmente comercializados diretamente ao consumidor.

2.3.6. Tendo analisado os dispositivos constitucionais diretamente aplicáveis e as normas - princípios e regras - por meio deles reconstruídas, bem como a Lei que foi editada pretensamente com base nelas, já se pode formular a indagação capital para o deslinde da controvérsia posta neste Parecer: a Constituição Federal decidiu o conflito entre o dever de proteger a liberdade de comunicação e de informação e o dever de proteger a saúde ou transferiu o poder de decidir ao Poder Legislativo? A Constituição Federal decidiu esse conflito por meio da instituição de regras, predeterminando o âmbito normativo de atuação do Poder Legislativo, sem deixar margem para uma ponderação livre e horizontal entre os princípios conflitantes, como se passa a demonstrar.

\subsection{A TÉCNICA NORMATIVA \\ UTILIZADA NO CASO E SUAS CONSEQÜENNCIAS ARGUMENTATIVAS}

\subsubsection{INSTITUIÇÃO DE REGRAS ESPECÍFICAS}

2.4.1.1. A Constituição Federal instituiu regras para solucionar o problema da propaganda comercial de tabaco. Ela não deixou aberta a questão estabelecendo, apenas, a proteção da saúde (art. 196), ou proteção da liberdade de informação e comunicação (art. $5^{\circ}$, IV, IX e XIV). Bem ao contrário. estabeleceu regras de atribuição, de exercício, de delimitação material e de reserva de competência.

2.4.1.2. Ao fazê-lo, como será demonstrado, a Constituição Federal afastou, de plano. a ponderação externa e horizontal de princípios em favor uma ponderação qualitativa e interna das razões constantes das próprias regras. É o que se passa a demonstrar.

2.4.1.3. O artigo 220 da Constituição Federal não apenas estabelece a liberdade de comunicação como algo a ser atingido, mas, em vez disso e de modo triplamente enfático, proíbe a escolha de qualquer meio - qualquer - que possa impedir a plenitude da liberdade de comunicação.

2.4.1.4. Com efeito, o referido dispositivo, primeiro, veda qualquer restrição à manifestação do pensamento, à criação, à expressão e à informação. Segundo, proíbe que qualquer lei contenha artigo que possa constituir embaraço à plena liberdade de informação. Terceiro, e não bastassem as duas proibições anteriores, o mencionado dispositivo ainda proíbe qualquer tipo de censura.

2.4.1.5. Sendo assim, a mera análise do caput do artigo 220 da Constituição revela a enunciação de três proibiçōes sucessivas, categóricas e incondicionais e manifesta a vontade da Constituição de forma clara, unidirecional e incondicional: a liberdade de comunicação dever ser livre. Ponto final.

2.4.1.6. É preciso insistir num aspecto: a mera leitura do caput do artigo 220 já revela que a Constituição Federal não se limitou a proteger a liberdade deixando aberta a escolha 
dos meios aptos a promovê-la; ela cuidou de excluir todos os meios que viessem a impedir a sua promoção. Junto com um princípio positivo relativamente à liberdade, há três regras negativas relativas a quaisquer meios que venham a restringi-la.

2.4.1.7. A Constituição Federal, porém, não pára por aí, indo mais longe para regular especificamente a propaganda comercial de tabaco ao instituir regra específica, que, de um lado, admite restrições, mas, de outro, só admite aquelas restrições que ela especifica. Com efeito, a linguagem do parágrafo $4^{\circ}$ do artigo 220 é clara: a "propaganda comercial de tabaco (...) estará sujeita a restrições legais, nos termos do inciso II do parágrafo anterior, e conterá, sempre que necessário. advertência sobre os malefícios decorrentes de seu uso". Ora, a Constituição não delega ao Poder Legislativo a competência para escolher quais serão as restrições a serem estabelecidas para a propaganda de tabaco. Nada mais equivocado do que afirmar que a Constituição teria afirmado que a publicidade estaria sujeita a restrições legais, sem defini-las de antemão. A Constituição, em vez disso, admite apenas as restrições indicadas no parágrafo anterior, e advertências sobre os malefícios do uso do tabaco. Só essas são as restrições permitidas. E nenhuma outra. A Constituição Federal poderia ter regulado a matéria de outra forma. Não o fez, porém.

2.4.1.8. E as restrições indicadas no referido parágrafo dizem respeito, apenas, ao estabelecimento de meios legais que garantam à pessoa e à família a possibilidade de se defenderem de programas ou programações de rádio e televisão que contrariem ao disposto no artigo 221 , bem como da propaganda de produtos, práticas e serviços que possam ser nocivos à saúde e ao meio ambiente. Vale dizer, cabe ao Poder Legislativo, ele próprio, criar condições que permitam que a pessoa e a família, elas próprias, possam se defender, tais como informá-las a respeito das características daquilo que estão consumindo, de tal sorte que possam ter condições de avaliar os riscos do consumo e o modo de agir relativamente a eles.

2.4.1.9. Mais do que isso sobre a propaganda de tabaco só a "advertência sobre os malefícios decorrentes de seu uso". Vale dizer, além de estabelecer os meios legais, o Poder Executivo ou Legislativo só poderá chamar a atenção dos consumidores para os malefícios do uso do tabaco. Mais e diferente do que isso, nada.

2.4.1.10. As observações anteriores já revelam que se está diante de um caso de aplicação de regras. Como se sabe, as normas não se confundem com os dispositivos a partir dos quais elas são reconstruídas. A partir de um único dispositivo podem ser reconstruídas várias normas. Com o disposto no artigo 220 da Constituição Federal não é diferente. Pode-se esmiuçar o dispositivo, diferenciando, de um lado, os diversos aspectos da competência que ele visa a regular (se atribuição, exercício. delimitação material ou reserva) e, de outro, os vários modais deônticos de que ele se vale para regular os comportamentos (se permitido, obrigatório ou proibido).' Todos esses aspectos são correlacionados, mas podem ser analiticamente discernidos, para serem devidamente compreendidos e, com isso, melhor aplicados. A interpretação do artigo 220 da Constituição Federal revela a instituição das seguintes regras.

2.4.1.11. Em primeiro lugar, analisando o dispositivo sob o ângulo da atribuição de competência, vê-se que ele gera três regras comportamentais: uma regra de conduta permissiva que permite ao Poder Legislativo estabelecer meios legais de defesa contra propaganda de produtos nocivos à saúde e exigir advertências sobre os malefícios do seu uso; uma regra de conduta proibitiva que proíbe a instituição de qualquer outra restrição à manifestação do pensamento, à criação, à expressão e à informação: e uma regra de conduta proibitiva que proíbe o Poder Executivo de exercer a mesma atividade. Além disso, o dispositivo gera uma regra constitutiva (definitória), na medida em que define determinada 
fonte (a lei) como apta a produzir determinados efeitos (estabelecer meios legais de defesa contra propaganda de produtos nocivos à saúde).

2.4.1.12. Em segundo lugar, desta feita examinando o dispositivo sob o ângulo do exercício da competência, constata-se que ele dá origem a uma regra de conduta obrigatória que obriga o Poder Público a seguir o procedimento parlamentar para exercer validamente o poder de criar meios legais de defesa contra a propaganda de produtos nocivos à saúde. Ademais, o dispositivo é fonte de regra constitutiva por regular um procedimento para o exercício de determinada competência, já que estabelece que a criação de meios de defesa deve obedecer ao procedimento parlamentar. Trata-se de uma regra definitória especificamente porque define como fonte normativa da criação dos meios legais de defesa somente aquela fonte que tenha sido produzida conforme o procedimento parlamentar.

2.4.1.13. Em terceiro lugar, agora investigando o dispositivo sob o ângulo da delimitação material de competência, verifica-se que ele é fonte de duas regras comportamentais: uma regra de conduta obrigatória que obriga o Poder Parlamentar a exercer o poder restritivo somente sobre determinadas matérias especificadas pela Constituição Federal (criação de meios legais de defesa contra a propaganda de produtos nocivos à saúde); e uma regra de conduta proibitiva que proíbe o Poder Parlamentar de exercer o poder de restringir a propaganda sobre outras matérias não abrangidas pelo campo material de incidência. Além disso, o dispositivo é fonte de regra constitutiva porque circunscreve o âmbito material de uma competência ao estabelecer que criação de meios legais de defesa contra a propaganda é matéria reservada ao Poder Legislativo.

2.4.1.14. Em quarto lugar, desta vez analisando o dispositivo sob o ângulo da reserva de competência, o aplicador pode reconstruir, conjuntamente, três normas: uma regra de conduta permissiva que atribui ao Poder Parlamentar o poder para criar meios legais de defesa contra a propaganda de produtos nocivos à saúde; uma regra de conduta proibitiva que proíbe o Poder Parlamentar de editar ou- tra fonte normativa não especificada pela Constituição Federal; e uma regra de conduta proibitiva que proíbe o Poder Parlamentar de delegar a outro sujeito o poder de editar leis relativamente à criação de meios legais de defesa contra a propaganda de produlos nocivos à saúde. O mesmo dispositivo, ademais. é fonte de regra constitutiva por reservar a determinada fonte normativa o poder para regular determinadas matérias, já que estabelece que somente a lei em sentido formal pode estabelecer os referidos meios de defesa contra a propaganda.

2.4.1.15. A verificação da dimensão normativa de regra das normas acima mencionadas traz consequiências para o aplicador. Com efeito, a característica dianteira das regras é a previsão de um comportamento a ser adotado ou de um efeito atribuído a um ato praticado ou fato ocorrido, como demonstrado. Diante de uma regra, o aplicador deve verificar se o ato praticado ou o fato ocorrido se encaixa no conceito da previsão normativa, como se passa a demonstrar.

\subsubsection{EFEITOS DECORRENTES DA INSTITUIÇÃO DE REGRAS ESPECÍFICAS}

\subsubsection{ESCOLHA DO MEIO DE ATUAÇÃO DO PODER PÚBLICO}

2.4.2.1.1. A análise das regras constitucionais mencionadas acima permite verificar que a Constituição não deixa aberta a escolha de qualquer outro meio de atuação do Poder Legislativo, por melhor que ele possa ser.

2.4.2.1.2. O Poder Legislativo só poderá (1) estabelecer meios de defesa para o consumidor de tabaco e (2) regular os casos de necessidade de a propagada conter advertência sobre malefícios do seu uso. Não se pode, portanto, sustentar que outros meios poderiam ser derivados de uma concepção doutrinária dos supostos deveres de proteção universalmente atribuiveis ao Estado. Afinal, como diz o Supremo Tribunal Federal, razões não suportadas pela Constituição "não podem legitimar o desrespeito e a afronta a princípios e valores 
sobre os quais tem assento o nosso sistema de direito constitucional positivo."'

\subsubsection{PRODUÇÃO DE UMA SOLUÇÃO PARA O CONFLITO ENTRE RAZÕES}

\subsection{As regras, ponderando previa-} mente todos aspectos relevantes sobre o conflito entre princípios, pretenderam estabelecer uma decisão para o conflito entre o dever de proteger a saúde e o dever de proteger a liberdade de comunicação.

2.4.2.2.2. Vale dizer, o Poder Legislativo não é livre para efetuar nova ponderação entre os valores em jogo e escolher qualquer outro meio, ainda que adequado, necessário ou proporcional relativamente à proteção da saúde. A ponderação já foi feita pelo Poder Constituinte, não cabendo ao poder constituído refazê-la. Nesse caso, por haver uma regra específica. " foi a Constituição mesma que ponderou os valores contrapostos" ? não cabendo ao Poder Legislativo fazer uma nova ponderação. Entender diferente é desrespeitar a Constituição, ao contrário do que manda o Supremo Tribunal Federal, quando diz: "A relação do Poder e de seus agentes, com a Constituição. há de ser, necessariamente, uma relação de respeito." 3

\subsubsection{EXCLUSÃO DE RAZÕES NA INTERPRETAÇÃO}

2.4.2.3.1. O efeito excludente das regras faz com que considerações variadas sobre a função do Estado na sociedade de informação e de risco, sobre a necessidade de colaboração do cidadão da atividade estatal, sobre a necessidade de diminuição dos gastos com tratamento, sobre a proteção do interesse geral ou sobre a necessidade de o Estado promover a saúde com a escolha de qualquer meio não tenham o condão de modificar a ponderação feita pelo próprio Poder Constituinte ao instituir uma regra. $O$ intérprete não pode sobrepor o seu modelo ideal de Estado àquele que é efetivamente estabelecido pela Constituição por meio das suas regras. Afinal, como diz o Supremo Tribunal Federal. em afirmação aplicável ao caso em pauta, a forma de atuação estatal de controle da propaganda de tabaco "...não pode ser conceituada a partir de um modelo ideal e apriorístico .... mas, sim, daquele que o constituinte originário concretamente adotou...".

2.4.2.3.2. Todos esses argumentos, muito comuns na interpretação de normas que tratam de matérias que envolvem forte apelo retórico, são excluídos pelo efeito decisório das regras. Como assevera o Supremo Tribunal Federal, por mais interessantes que possam parecer "... não devem prevalecer sobre o império da Constituição."

\subsubsection{VINCULAÇĀO ESTRUTURAL}

2.4.2.4.1. Em razão desse efeito excludente das regras, a existência de poder para restringir a propaganda não é descoberta por meio da ponderação quantitativa entre o interesse estatal de proteger a saúde e o interesse individual de proteger a liberdade, no sentido de que será admitida uma restrição tanto maior ao direito individual, quanto mais importante for a finalidade estatal perseguida. Até poderia ser assim, tivesse a Constituição Federal

I Supremo Tribunal Federal. Tribunal Pleno. Recurso Extraordinário n ${ }^{\circ}$ 150.764. Relator Ministro Sepúlveda Pertence, 16.12.92.

2 Habeas Corpus n 79.512-9. Tribunal Pleno, Relator Ministro Sepúlveda Pertence, DJ 16.05.03.

3 Açào Direta de Inconstitucionalidade $n^{\circ}$ 2010-MC. Relator Ministro Celso de Mello. DJ 12.04.02.

4 Ação Direta de Inconstitucionalidade. Relator Ministro Sepúlveda Pertence. DJ 01 12.2000.

5 Supremo Tribunal Federal. Tribunal Pleno, Recurso Extraordinário n ${ }^{\circ}$ 150.764. Relator Ministro Sepúlveda Pertence, 16.12.92. 
apenas instituído princípios em favor da proteção da saúde, aqui, e da proteção da liberdade de comunicação e informação, ali. Não foi essa, contudo, a técnica que a Constituição Federal efetivamente utilizou. Foi outra - a da instituição de regras específicas, proibitivas e categóricas sobre a publicidade comercial de produtos.

2.4.2.4.2. Sendo assim, a existência de poder para restringir a propaganda é desvelada por meio de uma análise qualitativa que investiga a estrutura do poder atribuído. E desse âmbito estão excluídas aquelas razões, ainda que interessantes e retoricamente impressionantes, que digam respeito à proteção da saúde, em virtude da já mencionada eficácia excludente das regras. ' $\mathrm{O}$ fundamento para criar outras restrições, do mesmo modo do que ocorreria, por exemplo, com a publicidade religiosa por parte do Estado, "são inconstitucionais, porque as únicas justificativas que podem ser oferecidas a elas envolvem princípios e razões que são excluídas constitucionalmente como um fundamento para a ação estatal." ?

\subsubsection{VINCULAÇÃO DEFINITÓRIA}

\subsection{VINCULAÇÃO À LINGUAGEM CONSTITUCIONAL}

2.4.2.5.1.1. Tendo sido instituídas regras, que descrevem os meios a serem utilizados pelo Poder Legislativo, o aplicador está vinculado à descoberta do significado mínimo das palavras usadas pela Constituição. Ainda que exista alguma margem de indeterminação na linguagem, o intérprete está adstrito aos seus significados mínimos. pois ele. como diz o Supremo Tribunal Federal, “... não deve ir além dos limites semânticos, que são intransponíveis".

\subsection{O TERMO "PROPAGANDA COMERCIAL” E SUUA DEFINIÇÃO}

\subsection{Nesse sentido, é preciso saber} qual o significado da expressão "propaganda comercial" no dispositivo em comento.

2.4.2.5.2.2. Como já mencionado anteriormente, quando a Constituição utiliza um termo, das duas, uma: ou ela põe o conceito, no texto ou no contexto constitucional, conotando os predicados que o compõem; ou ela pressupõe o conceito, incorporando um conceito pré-constitucional utilizado pela legislação ao tempo da promulgação da Constituição. Esses caminhos não se excluem necessariamente. podendo se complementar. ${ }^{4}$

2.4.2.5.2.3. É o que ocorre no caso: o conceito dos termos utilizados pelo artigo $220 \mathrm{da}$ Constituição Federal pode ser definido direta ou indiretamente. Em primeiro lugar, é preciso notar que, a Constituição, ao dizer, no parágrafo $4^{\circ}$ do artigo 220 , que a "propaganda comercial de tabaco (...) estará sujeita a restrições legais, nos termos do inciso II do parágrafo anterior...", o fez no capítulo da "Comunicação Social", onde são reguladas, justamente, as atividades dos veículos de comunicação de massa, como jornais e rádios. Pelo contexto, portanto, não há dúvida de que se trata da restrição à atividade de veiculação de mensagens para o público em geral e em meios de comunicação de massa.

1 SCHAUER, Frederick. Profiles, Probabilities and Stereotypes. Cambridge: Harvard University Press, 2003. p. 104-105.

2 PILDES. Richard H.. Avoiding Balancing: The Role of Exclusionary Reasons in Constitutional Law Hastings Law Journal. v. 45, n. 4, abr./1994, p. 726

3 Recurso Extraordinário n 71.758. Relator Ministro Thompson Flores, RTJ 66. p. 150.

4 ÁVILA. Humberto. A Eficácia do Novo Código Civil na Legislação tributária. In: GRUPPENMACHER, Betina (Org.). Direito Tributário e o Novo Código Civil. São Paulo: Quartier Latin, 2004. p. 65. 
2.4.2.5.2.4. Em segundo lugar, é necessário atentar para o fato de que a Constituição utilizou a expressão "propaganda comercial", o que pressupõe, de um lado, condições de divulgação de um produto para a venda $e$. de outro, possibilidade de persuasão de alguém que ainda não seja consumidor. Fazer propaganda comercial pressupōe disputar a preferência do consumidor, o que, por sua vez, pressupõe tornar público o produto. Em outras palavras, a propaganda comercial requer, de um lado, a divulgação do produto necessariamente além do espaço interno dos locais de venda; de outro, a propaganda comercial, como veículo de comunicação social, pressupõe a divulgação nos veículos de comunicação social, como o são os jornais e rádios.

2.4.2.5.2.5. Em terceiro lugar, é preciso notar que a Constituição Federal usou o termo "propaganda”. Quando a Constituição utiliza um termo, sem conceituá-lo de modo diverso. ela incorpora o conceito que é utilizado no direito infra-constitucional anterior à promulgação da Constituição.

2.4.2.5.2.6. Esse é o entendimento reiterado do Supremo Tribunal Federal. Por exemplo, quando a Constituição usou o termo "salário", fez referência ao seu conceito pelo Direito do Trabalho no sentido de remuneração paga pelo empregador ao empregado'; quando usou o termo "mercadoria", incorporou o conceito do Direito Comercial no sentido de objeto móvel inserido no comércio ${ }^{2}$; quando usou o termo "serviços", incorporou o conceito do Direito Civil no sentido de obrigação de dar ${ }^{3}$; e assim sucessivamente. Isso significa que, ao utilizar um termo sem apresentar um novo conceito, a Constituição Federal incorpora o conceito legalmente praticado à época da sua promulgação.

2.4.2.5.2.7. Ora, analisando-se a legislação infraconstitucional anterior à promulgação da Constituição Federal de 1988, vê-se que o termo "propaganda" era conceituado pela Lei $n^{\circ} 4.680 / 65$, que dispõe sobre o exercício da profissão de publicitário e de agenciador de propaganda, da seguinte forma:

Art. $4^{\circ}$ São veículos de divulgação, para os efeitos desta Lei, quaisquer meios de comunicação visual ou auditiva capazes de transmitir mensagens de propaganda ao público, desde que reconhecidos pelas entidades e órgãos de classe, assim considerados as associações civis locais e regionais de propaganda bem como os sindicatos de publicitários.

Art. $5^{\circ}$ Compreende-se por propaganda qualquer forma remunerada de difusão de idéias, mercadorias ou serviços, por parte de um anunciante identificado.

2.4.2.5.2.8. A mera leitura da legislação aplicável à época da promulgação da Constituição de 1988 reitera a leitura contextual do artigo 220 na medida em que permite verificar que a Constituição incorporou o conceito de propaganda como "qualquer forma remunerada de difusão de idéias, mercadorias ou serviços, por parte de um anunciante identificado". significando difusão a transmissão de "mensagens de propaganda ao público". Isso significa, em outras palavras, que a Constituição Federal incorporou o conceito de propaganda como sendo o meio para a divulgação de idéias para o público em geral, por meio de veículos de comunicação de massa. Em outras palavras, "propaganda" limitada aos locais internos de venda, por meio de pôsteres, painéis e cartazes não é, a rigor, propaganda no sentido constitucionalmente posto $\mathrm{e}$ pressuposto.

2.4.2.5.2.9. É oportuno lembrar que a Constituição Federal, ao incorporar o conceito de propaganda como "qualquer forma remunerada de difusão de idéias", optou pela incorporação do conceito mais amplo possível de propaganda, não podendo o legislador infraconstitucional, a pretexto de concretizar o

I Recurso Extraordinário n 166.772-9, Relator Ministro Marco Aurélio, DJ 16.12.94.

2 Recurso Extraordinário n 203.075-9. Relator Ministro Maurício Corrêa. DJ 29.10.99.

3 Recurso Extraordinário n 116.121-3. Relator Ministro Octávio Gallotti. DJ 25.05.01. 
mandamento constitucional amplo, escolher uma só forma restrita de "difusão" de idéias quando a Constituição Federal já escolheu todas. Ademais, é preciso enfatizar que a locução "qualquer forma" diz respeito a "difusão de idéias", o que, por si só, implica disseminação, divulgação e irradiação de idéias, em tudo e por tudo incompatível com a limitação da propaganda aos locais internos de venda. Vale dizer, a restrição da propaganda aos locais internos de venda não só colide com o sentido mínimo de "qualquer forma", por restringir algo que a Constituição Federal quis ampliar, mas, de resto, ainda contraria o sentido nuclear da expressão "difusão de idéias", por admitir a "propaganda" sem a essencial difusão de idéias.

\subsection{O TERMO “ ADVERTÊNCIA" E SUA DEFINIÇĀO}

2.4.2.5.3.1. De outro lado, é preciso saber qual o significado da expressão " advertência sobre os malefícios do uso" do tabaco. Isso porque, mesmo admitindo a vinculação à linguagem constitucional, poder-se-ia sustentar que ela, sendo elevadamente indeterminada, terminaria por atribuir amplo poder discricionário ao Poder Legislativo. Vale dizer, mesmo aceitando que o Poder Legislativo está adstrito à criação de meios de defesa e, quando necessário, à colocação de "advertência sobre os malefícios do uso" do tabaco, poderse-ia sustentar que no poder de emitir uma "advertência" estaria incluído, de um lado, o poder para desestimular ou proibir o uso do tabaco e, de outro, o poder para veicular imagens relativamente aos danos provocados pelo consumo do tabaco. A essa conclusão, porém, não se pode chegar.

2.4.2.5.3.2. Para definir o âmbito de abrangência da palavra "advertência" é preciso, em primeiro lugar, verificar, no ordenamento constitucional, o tipo de expressões que são utilizadas para a atribuição de competência e. com isso, mediante comparação, examinar o significado contextualmente possível para o termo "advertência".

2.4.2.5.3.3. A jurisprudência do Supremo Tribunal Federal é firme no sentido de que o intérprete não pode desprezar o sentido vernacular das palavras usadas pela Constituição da República Federativa do Brasil de 1988.' Assim como a Constituição utiliza o termo "advertência", ela também usa os termos "desestimular" (art. 153, \$ 4", I), "combater" (art. 23, X), "impedir" (art. 23, II e IV), "projbir" (art. $7^{\circ}, \mathrm{XXX}$ e ss., art. 17, II e XVII e art. $165, \S 8^{\circ}$ ), "veicular imagens" (art. 21 , XII, “a”, art. $37, \S 1^{\circ}$. art. $155, \S 2^{\circ}, \mathrm{X}$, , d", art. 222) e "caráter informativo da publicidade pública" (art. $37 \S 1^{\circ}$ ).

2.4.2.5.3.4. Ora, compreender, no conceito de advertência, o poder de desestimular ou proibir, e atribuir à advertência um caráter anti-persuasivo. quando essas palavras foram usadas no mesmo ordenamento constitucional é aproximar conceitualmente termos que ele conceitualmente distancia, em flagrante afronta à Constituição. Em outras palavras, o intérprete não poderá incluir, no conceito de advertência, o poder de desestimular ou proibir o consumo de tabaco, o poder de exercer atuações informativas, nem o poder de veicular imagens a título de contrapropaganda, a pretexto de reforçar o conteúdo das mensagens, sob pena de afronta à Constituição. Quisesse o Poder Constituinte incluir, no conceito de advertência, também esses poderes, o teria feito usando palavras que usou noutros dispositivos. Não o fez, porém. Não cabe ao intérprete fazê-lo.

2.4.2.5.3.5. Outro caminho para definir o âmbito de abragência da "advertência" é recorrer aos princípios constitucionais para verificar qual tipo de interpretação eles, no seu conjunto, suportam.

2.4.2.5.3.6. Esse método é extremamente importante, dado que muitos sustentam que o poder de emitir uma "advertência" inclui o poder de desestimular ou proibir o uso do

1 Supremo Tribunal Federal, Tribunal Pleno, Recurso Extraordinário n ${ }^{\circ}$ 66.772-9-RS, Relator Ministro Marco Aurélio, DOU 12.05.94. 
tabaco com base em argumentos históricos ou pragmáticos: históricos no sentido de que, historicamente, o conceito clássico de poder de polícia envolveria o poder de limitar de qualquer forma a atividade do particular; e pragmáticos no sentido de que o poder público só conseguiria atingir os seus fins, na sociedade de risco atual, se dispusesse de todos os meios. Esses argumentos, porém, devem ceder passo aos argumentos relativos à linguagem constitucional.

2.4.2.5.3.7. Isso porque existem vários argumentos que podem ser utilizados na interpretação constitucional, mas nem todos têm o mesmo peso. Os argumentos linguí́sticos são aqueles que dizem respeito ao significado dos dispositivos ou enunciados prescritivos, tanto ao significado das expressões quanto a sua estrutura gramatical. Os argumentos sistemáticos são aqueles que são fundados na estrutura do sistema jurídico e dizem respeito aos seus elementos ou a sua aplicação. Os argumentos genéticos são aqueles que dizem respeito à vontade do legislador, tanto no que se refere ao significado que o legislador teria ligado a determinada expressão, quanto à finalidade que ele teria pretendido atingir. Os argumentos históricos são aqueles que dizem respeito à investigação do problema objeto de regulação pelas normas hoje válidas, de modo a recompor o sentido que a norma tinha ao ser editada. E os argumentos meramente práticos são aqueles que dependem de um julgamento, feito pelo próprio intérprete, sob pontos de vista econômicos, políticos ou éticos.

2.4.2.5.3.8. Se há vários argumentos, pergunta-se: quais deles devem prevalecer $\mathrm{e}$ como encontrar a resposta? Aqui entram em cena os princípios constitucionais, pois são eles que devem orientar as regras de prevalência entre os argumentos. A realização dos princípios constitucionais deve-se viabilizar também pela argumentação: efetivar os prin- cípios fundamentais é incorporar, na própria argumentação, aquilo que eles próprios determinam. Nesse sentido. os princípios do Estado de Direito, da separação dos poderes e da legalidade estabelecem a prioridade dos argumentos linguísticos e sistemáticos sobre os argumentos meramente pragmáticos. Aquilo que foi dito pelo legislador deve prevalecer sobre aquilo que ele, embora desejasse, deixou de dizer. ${ }^{\prime}$

2.4.2.5.3.9. Para o caso em pauta, isso significa, primeiro, que os argumentos históricos não podem se sobrepor aos argumentos linguísticos, como assevera o Supremo Tribunal Federal, quando afirma que "O conteúdo político de uma Constituição não é conducente ao desprezo do conteúdo vernacular das palavras..."2 Segundo, que os argumentos pragmáticos não podem se sobrepor aos argumentos sistemáticos, como exige o Supremo Tribunal Federal, quando afirma que " Argumentos de necessidade, por mais relevantes que possam ser. não devem prevalecer sobre o império da Constituição." "

2.4.2.5.3.10. Isso significa, para o caso em pauta, que o conceito de advertência dever ser buscado no próprio ordenamento constitucional, sendo de pouca valia argumentos que não sejam com ele compatíveis, mesmo que baseados em conceitos supostamente clássicos de poder de polícia ou em concepções pretensamente universais de Estado. E, nesse sentido, o ordenamento constitucional, interpretado sistematicamente, conduz a um significado de "advertência" que não inclui, de modo algum, quer o desestímulo ou a proibição, quer a veiculação de imagens com efeito de contrapropaganda. Ela inclui, apenas, a indicação dos malefícios do uso do tabaco, a ser feita por quem faz a propaganda. Outras informações e outros modos de prestá-las cabem, nos limites constitucionais, à publicida de pública.

1 ÁVILA, Humberto. Argumentação jurídica e a imunidade do livro eletrônico. Revista de Direito Tributário (79):163-183. São Paulo: Malheiros, 2001.

2 Recurso Extraordinário $n^{\circ}$ 166.772-9-RS, Tribunal Pleno, Relator Ministro Marco Aurélio. DOU 12.05.94.

3 Recurso Extraordinário n 150.764, Tribunal Pleno, Relator Ministro Sepúlveda Pertence, 16.12.92. 


\subsubsection{JUSTIFICATIVA PARA A ADOÇÃO DE REGRAS NO CASO}

2.4.3.1. Há sobejos motivos para a restrição constitucional das restrições legais. É que, se a Constituição Federal não tivesse preestabelecido os meios de restrição da propaganda, os Poderes Executivo e Legislativo poderiam, caso a caso e conforme os sabores do momento, criar restrições, colocando em risco a realização de princípios reputados fundamentais pela própria linguagem constitucional. Com a introdução de uma restrição aqui, outra acolá, de pouco em pouco os princípios da liberdade de comunicação e de informação estariam sendo restringidos de forma arbitrária $\mathrm{e}$ em demasia. É justamente para evitar os equívocos gerados pela discricionariedade que a Constituição Federal instituiu regras a respeito das restrições admissíveis à propaganda de alguns produtos, na assunção de que. assim o fazendo, estaria produzindo menos equívocos do que aqueles que seriam cometidos na ausência da regra. Atentando para esse fato característico das regras, assim se pronuncia SCHAUER:

"Seguir diretrizes simples em um processo complexo irá, certamente, gerar equívocos, mas nós sabemos que também a discricionariedade gera equívocos. Por consequência, um argumento a favor das diretrizes é o de que, embora elas produzam equívocos, elas produzem menos equívocos do que a alternativa."

2.4.3.2. Esse é, precisamente, o caso deste Parecer. Foi para evitar os malefícios que adviriam da atribuição de discricionaridade para a fixação de restrições que a Constituição Federal, ela própria, já definiu quais são as restrições admissíveis. Essa opção fica clara quando são analisados os dispositivos das constituições pretéritas sobre a matéria.

2.4.3.3. A Constituição Federal de 1967, no seu artigo 150, assim normatizava a matéria:

$\S 8^{\circ}$ - É livre a manifestação de pensamento, de convicção política ou filosófica e a prestação de informação sem sujeição à censura, salvo quanto a espetáculos de diversões públicas, respondendo cada um, nos termos da lei, pelos abusos que cometer. É assegurado o direito de resposta. A publicação de livros, jornais e periódicos independe de licença da autoridade. Não será, porém, tolerada a propaganda de guerra, de subversão da ordem ou de preconceitos de raça ou de classe.

2.4.3.4. A Emenda Constitucional $\mathrm{n}^{\circ} 1$, de 1969, no seu artigo 153, modificou a Constituição Federal de 1967, da seguinte forma:

$\S 8^{\circ}$ - É livre a manifestação de pensamento, de convicção política ou filosófica, bem como a prestação de informação independentemente de censura, salvo quanto a diversōes e espetáculos públicos, respondendo cada um, nos termos de lei, pelos abusos que cometer. (...) Não serão, porém, toleradas a propaganda de guerra, de subversão da ordem ou de preconceitos de religião, raça ou de classe, e as (...) exteriorizações contrárias à moral e aos bons costumes.

2.4.3.5. Ora, foi justamente para afastar, de um lado, a incerteza com relação ao significado de "abusos", "subversão da ordem", "moral e bons costumes" e, de outro, a arbitrariedade que poderia surgir na definição desses termos pelo Poder Legislativo que a Constituição de 1988 inovou. E inovou criando regras que já estabelecem quais são as restrições permitidas, "nos termos desta Constituição".

\subsection{EXAME DE \\ CONSTITUCIONALIDADE DA LEI ${ }^{\circ}$ 9.294/96 E ALTERAÇÕES}

\subsubsection{VIOLAÇÃO FRONTAL ÀS REGRAS CONSTITUCIONAIS APLICÁVEIS}

2.5.1.1. A análise anterior revelou que a Constituição Federal, diferentemente de apenas instituir princípios que protejam a saúde e a liberdade de comunicação e informação, estabeleceu regras proibindo qualquer tipo de

1 SCHAUER. Frederick. Profiles, Probabilities and Stereotypes. Cambridge: Harvard University Press, 2003. p. 259. 
restrição à comunicação, bem como, com relação à propaganda de tabaco, admitiu, tão-só, a criação de dois tipos de restriçōes: de um lado, a instituição de meios legais de defesa do consumidor e, de outro, a colocação de advertências sobre os malefícios do uso do tabaco.

2.5.1.2. Tendo as regras eficácia decisiva e excludente, as razões, baseadas no princípio da proteção da saúde, não afastam as regras específicas que proíbem a criação de quaisquer outras restrições diferentes daquelas admitidas "nos termos desta Constituição".

2.5.1.3. Diante desse quadro, resta investigar a natureza das restrições criadas pela Lei $n^{\circ}$ 9.294/96 e suas posteriores modificações à propaganda do tabaco e, posteriormente, a compatibilidade dessas restrições com a Constituição Federal.

2.5.1.4. A mera leitura do artigo $3^{\circ}$ da Lei $n^{\circ} 9.294 / 96$, acima reproduzido, já revela a criação de uma restrição que nada tem a ver com a criação de meios legais ou com a colocação de advertências quanto ao uso do tabaco. Com efeito, as restrições criadas pela Lei dizem respeito ao modo e ao local da propaganda, pois estabelecem que ela "só poderá ser efetuada através de pôsteres, painéis e cartazes, na parte interna dos locais de venda". Ora, não tendo a limitação do local e do modo qualquer relação com meios legais para que a pessoa e a família possa avaliar, elas próprias, o risco e a razoabilidade do consumo ou com a colocação de advertências, claro está que essas restrições não são permitidas pela Constituição. Não sendo nenhuma das espécies de restrições constitucionalmente permitidas, sai-se do seu campo de incidência, e a limitação do modo e do local da propaganda termina esbarrando no comando constitucional que estabelece que a "manifestação do pensamento, a criação, a expressão e a informação, sob qualquer forma, processo ou veículo não sofrerão qualquer restrição".

\subsubsection{VIOLAÇÃO DO NÚCLEO DOS DIREITOS FUNDAMENTAIS}

2.5.2.1. A investigação feita acima revelou que a Constịtuição Federal, de acordo com a jurisprudência do Supremo Tribunal Federal, não permite nem a restrição excessiva de um direito fundamental. Para esse efeito, considera-se excessiva aquela medida que o inviabiliza substancialmente. independentemente do seu motivo, nem o cerceamento que dificulte sobremaneira o livre exercício da atividade econômica, ainda que a medida estatal não o inviabilize por completo.

2.5.2.2. A mera leitura do artigo $3^{\circ}$ da Lei n 9.294/96 já evidencia que as "restrições" criadas impedem a publicidade e a propaganda de produtos lícitos, na medida em que restringem a propaganda ao local de venda e a cartazes. Com essa restrição, na verdade, não há sequer exercício do direito de comunicação. A rigor, portanto, a Lei não cria restrições. Ela estabelece uma proibição, algo bem diverso.

2.5.2.3. De outro turno. essas restriçōes terminam por inviabilizar a divulgação de produtos lícitos, afetando, substancialmente, o direito fundamental de livre exercício de atividade econômica.

2.5.2.4. De fato, sem poder divulgar um produto novo, na verdade as empresas se vêem impedidas de exercer sua atividade econômica, na medida em que, para disputar a preferência do consumidor é necessário informá-lo do novo produto, sem o que ele não irá comprar ou se esclarecer.

\subsection{CONCLUSÕES}

2.6.1. Todas as considerações anteriores permitem chegar às seguintes conclusões a respeito do caso posto neste parecer:

(1) a Constituição Federal instituiu regras para solucionar o conflito entre os princípios da proteção da saúde e da liberdade de comunicação e informação que pode surgir no caso de propaganda de produtos fumigeros;

(2) a opção constitucional por regras escoThe meios de atuação do poder público no que se refere à restrição da propaganda de tabaco; produz uma solução para o conflito entre o dever de proteger a saúde. de um lado, e de proteger a liberdade de comunicação e de informação, de outro; exclui da interpretação 
tanto alegações relativas à ausência total de restrições às liberdades quanto alegações a respeito da proteção irrestrita do interesse público; afasta a ponderação livre e horizontal entre princípios conflitantes pelo Poder Legislativo e conduz a uma interpretação por correspondência conceitual, também entendida por ponderação interna e vertical das regras aplicáveis; e vincula o aplicador aos limites semânticos postos ou pressupostos pela Constituição Federal;

(3) a Constituição Federal veda qualquer restrição à liberdade de comunicação e informação, admitindo, tão-só, que o Poder Legislativo crie meios de defesa para que a pessoa e a família se defendam de propagandas de produtos nocivos à saúde e que exija a colocação de advertências sobre os malefícios do seu consumo;

(4) ao permitir o estabelecimento de meios de defesa a Constituição Federal atribuiu ao Poder Legislativo a incumbência de criar condições para que a pessoa e a família possam avaliar o risco e a razoabilidade do consumo do tabaco, munindo-os de informações atualizadas para um auto-julgamento e uma autodefesa;

(5) ao inserir o poder para restringir a propaganda no capítulo da "Comunicação Social" e ao utilizar o termo "propaganda comercial", a Constituição Federal, além de pressupor a licitude da comercialização e propaganda de produtos fumígeros, pôs e pressupôs o conceito de propaganda como transmissão de mensagens ao público por meio de qualquer veículo de comunicação;

(6) ao usar o termo "advertência", ao lado de outros termos como "proibir" e "desestimular", a Constituição Federal excluiu do conceito de advertência a contrapropaganda com a finalidade de desestimular, cabendo a quem faz a propaganda fazer a advertência, sendo outras informações reservadas à publicidade pública às suas expensas, por expressa disposição constitucional;

(7) ao estabelecer os princípios da liberdade de comunicação, de informação e de livre exercício de atividade econômica, a Consti- tuição Federal vedou, indiretamente, a restrição de bens jurídicos sem os quais eles perdem sua eficácia mínima, aí incluída a disponibilidade para se comunicar pelos meios de comunicação de massa e a disponibilidade para disputar, via propaganda comercial. clientes para produtos lícitos;

(8) a Lei $n^{\circ} 9.294 / 96$, e suas posteriores modificações, ao estabelecer que a propaganda comercial de produtos fumígeros só poderá ser feita por meio de pôsteres, painéis e cartazes na parte interna dos locais de venda, viola as regras constitucionais que apenas permitem a criação de meios de defesa para a pessoa e a família se protegerem de propagandas de produtos nocivos à saúde; a restrição constitucional a outras restrições legais garante a propaganda comercial dos produtos nos veículos de comunicação de massa, como rádios e jornais:

(9) a Lei $n^{\circ} 9.294 / 96$. e suas posteriores modificações, ao exigir a veiculação de imagens e de mensagens de contrapropaganda, viola as regras constitucionais que apenas exigem advertência sobre os malefícios do fumo, cabendo à propaganda pública outros elementos informativos.

(10) a Lei $n^{\circ} 9.294 / 96$. e suas posteriores modificações, ao estabelecer que a propaganda comercial de produtos fumígeros só poderá ser feita por meio de pôsteres, painéis e cartazes na parte interna dos locais de venda, restringe excessivamente os princípios da liberdade de informação (art. $5^{\circ}, \mathrm{XIV}$ ), de comunicação (art. $5^{\circ}$, IV e IX) e de livre exercício de atividade econômica (art. 170), que pressupõem o direito de fazer propaganda comercial de produtos lícitos através dos meios de comunicação.

(11) sendo declarada inconstitucional a Lei $n^{\circ}$ 9.294/96, que revogou as disposições em contrário (art. 12), recobra eficácia a legislação anterior.

Este é o meu parecer, s.m.j.

Porto Alegre, 16 de maio de 2005.

PROF. DR. HUMBERTO ÁVILA

Doutor em Direito e Especialista em Metodologia da Ciência do Direito pela Univer- 
sidade de Munique, República Federal da Alemanha. Mestre em Direito pela Faculdade de Direito e Especialista em Finanças pela Faculdade de Ciências Econômicas da Universidade Federal do Rio Grande do Sul. Professor Adjunto Concursado de Direito Tributário, Financeiro e Econômico da Faculdade de Direito da Universidade Federal do Rio Grande do Sul, onde é Professor dos Cursos de Mestrado e Doutorado. Professor Visitante dos Cursos de Mestrado e Doutorado da Universidade Estadual do Rio de Janeiro. Presidente do Instituto Internacional de Estudos de Direito do Estado - IIEDE. Advogado, Consultor e Parecerista em Porto Alegre. 